\title{
Does the Evidence Favor State Competition in Corporate Law
}

\section{Citation}

Lucian Bebchuk, Alma Cohen \& Allen Ferrell, Does the Evidence Favor State Competition in Corporate Law, 90 Calif. L. Rev. 1775 (2002).

\section{Published Version}

http://scholarship.law.berkeley.edu/californialawreview/vol90/iss6/1/

\section{Permanent link}

http://nrs.harvard.edu/urn-3:HUL.InstRepos:12965069

\section{Terms of Use}

This article was downloaded from Harvard University's DASH repository, and is made available under the terms and conditions applicable to Other Posted Material, as set forth at http:// nrs.harvard.edu/urn-3:HUL.InstRepos:dash.current.terms-of-use\#LAA

\section{Share Your Story}

The Harvard community has made this article openly available.

Please share how this access benefits you. Submit a story.

\section{Accessibility}




\section{California Law Review}

Volume 90 | Issue 6

Article 1

December 2002

\section{Does the Evidence Favor State Competition in Corporate Law}

Lucian Bebchuk

Alma Cohen

Allen Ferrell

Follow this and additional works at: http://scholarship.law.berkeley.edu/californialawreview

\section{Recommended Citation}

Lucian Bebchuk, Alma Cohen, and Allen Ferrell, Does the Evidence Favor State Competition in Corporate Law, 90 CAL. L. REv. 1775 (2002).

Available at: http://scholarship.law.berkeley.edu/californialawreview/vol90/iss6/1

This Article is brought to you for free and open access by the California Law Review at Berkeley Law Scholarship Repository. It has been accepted for inclusion in California Law Review by an authorized administrator of Berkeley Law Scholarship Repository. For more information, please contact jcera@law.berkeley.edu. 


\section{California Law Review}

\begin{tabular}{lll}
\hline \hline Vol. 90 & DeCEMBER 2002 & No.6 \\
\hline \hline
\end{tabular}

Copyright $@ 2002$ by California Law Review, Inc.

\section{Does the Evidence Favor State Competition in Corporate Law?}

\section{Lucian Bebchuk, $\dagger$ Alma Cohen, $\dot{\dagger}$ and Allen Ferrell $\dagger \ddagger$}

\section{TABLE OF CONTENTS}

Introduction

I. Does Delaware Incorporation Increase Shareholder Value?

A. Tobin's Q Differences Between Delaware and

Non-Delaware Corporations

1. The Current Nonexistence of Correlation ........................... 1785

2. The Fluctuations of the "Delaware Effect" ........................ 1786

3. The Problem of Selection .................................................. 1788

a. Selection Follows from the Very Presence of a

Delaware Wealth Effect

b. Understanding Selection

B. Event Studies of Reincorporations

I. The Abnormal Returns Findings: Questions of

Robustness and Magnitude.

2. The Problem of Confounding Events............................... 1792

a. Confounding Events

Copyright $₫ 2002$ Lucian Bebchuk, Alma Cohen, and Allen Ferrell.

$\dagger \quad$ William J. Friedman \& Alicia Townsend Friedman Professor of Law, Economics and Finance, Harvard Law School; Research Associate, National Bureau of Economic Research and Center for Economic Policy Research.

* Postdoctoral Fellow, National Bureau of Economic Research.

it Assistant Professor of Law, Harvard Law School.

We are grateful to Steve Choi, James Cox, Jill Fisch, Jesse Fried, Assaf Hamdani, Bert Huang, Marcel Kahan, Jason Knott, Roberta Romano, Erich Schanz, Lynn Stout, Guhan Subramanian and workshop participants at the University of Marburg, Canadian Law and Economics Society Meeting and the Harvard Law and Economics Workshop for valuable suggestions and discussions. Lucian Bebchuk and Allen Ferrell are grateful to the John M. Olin Center for Law, Economics and Business at Harvard Law School for its financial support. 
b. Scheduling Reincorporation Votes in Relatively Good Times 1794

c. Increased Likelihood of Takeover 1795

d. Different Reincorporation Categories 1796

II. Does a Marginal Superiority of Delaware Incorporation Imply that State Competition Benefits Investors?

A. The Need to Evaluate States' Collective Performance 1798

B. A Skeptical Account of State Competition Is Consistent with Delaware Marginal Superiority

III. Does State Competition Work Well in the Area of Takeover Regulation?

A. The View that States Restrict Takeovers Excessively 1800

B. Claims that Delaware Corporations Are Acquired More Often 1802

C. Claims that Delaware's Takeover Law Is Relatively Moderate 1803

D. Claims that Outlier States Have Been Penalized 1804

E. Claims that Antitakeover Statutes Are Outside the Parameters of State Competition 1806

IV. Recent Evidence on the Determinants of Incorporation Decisions. 1806

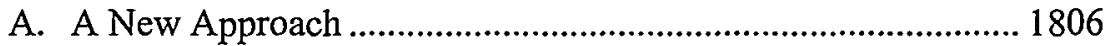

B. The Pattern of Incorporations ............................................... 1808

C. The Landscape of State Antitakeover Statutes ....................... 18I2

D. Do Antitakeover Statutes Help States Retain In-State Companies?

E. Do Antitakeover Statutes Help States Attract Out-of-State Companies?

F. Reconsidering Established Positions 1818

Conclusion 


\section{Does the Evidence Favor State Competition in Corporate Law?}

\section{Lucian Bebchuk, Alma Cohen, and Allen Ferrell}

In the ongoing debate on state competition over corporate charters, supporters of state competition have long claimed that the empirical evidence clearly supports their view. This Article suggests that the body of empirical evidence on which supporters of state competition have relied does not warrant this claim. This empirical evidence, the authors show, is in fact entirely consistent with the opposing view that state competition provides undesirable incentives with respect to some corporate issues, such as takeover regulation, that substantially affect corporate managers' private interests.

The authors first demonstrate that reported findings of a positive correlation between incorporation in Delaware and increased shareholder wealth are not robust and, furthermore, do not establish causation. Second, the authors show that, even if Delaware incorporation were found to cause an increase in shareholder value, this finding would not imply that state competition is working well; benefits to incorporating in the dominant state would likely exist in a "race toward the bottom" equilibrium in which state competition provided undesirable incentives. Third, the authors point out that empirical claims that state competition rewards moderation in the provision of antitakeover protections are not well grounded. Finally, the authors endorse a new approach to the empirical study of the subject that is based on analyzing the determinants of companies' choices of state of incorporation. Recent work based on this approach indicates that, contrary to the beliefs of state-competition supporters, states that amass antitakeover statutes are more successful in the incorporation market. The authors' analysis calls for a reconsideration of established positions concerning the merits and consequences of regulatory competition (as currently structured) in corporate law.

\section{INTRODUCTION}

One of the most central and enduring debates in corporate law scholarship concerns the role of states in the regulation of corporations. Simply put, what are the costs and benefits of allowing a firm, through its incorporation decision, to select which state's corporate law governs its activities? The modern debate on the subject, which began with William Cary's attack 
on state competition as fostering a "race to the bottom,"1 has produced a voluminous literature. ${ }^{2}$ The debate has had remarkable resiliency; in recent years there has been a burst of writing by legal academics weighing in on the subject. ${ }^{3}$ Nor is interest any longer confined to U.S. academics; European policymakers now face the pressing question of how to allocate regulatory authority between the institutions of the European Union and its member national governments in the area of corporate law. ${ }^{4}$

The dominant view among corporate law scholars has been the "race to the top" school of thought. Its supporters contend that the competition among states over attracting incorporations benefits shareholders. ${ }^{5}$ On their view, Delaware, the dominant state for incorporations, has "won" the race for incorporations by being the most virtuous, that is, by offering rules that maximize shareholder wealth. Indeed, one prominent "race to the top" theorist has referred to state competition as the "genius of American corporate law."6

1. William L. Cary, Federalism and Corporate Law: Reflections Upon Delaware, 83 YALE L.J. 663 (1974).

2. See, e.g., Frank H. Easterbrook \& Daniel R. Fischel, The Economic Structure of Corporate law 1-40 (1991); Roberta Romano, the Genius of american Corporate law (1993) [hereinafter Romano, Genius]; Lucian A. Bebchuk, Federalism and the Corporation: The Desirable Limits on State Competition in Corporate Law, 105 HARv. L. Rev. 1435 (1992); Roberta Romano, Law as a Product: Some Pieces of the Incorporation Puzzle, 1 J.L. Econ. \& Org. 225 (1985) [hereinafter Romano, Law as a Product]; Ralph K. Winter, Jr., State Law, Shareholder Protection, and the Theory of the Corporation, 6 J. LEGAL STUD. 251 (1977).

3. See, e.g., Lucian A. Bebchuk \& Allen Ferrell, A New Approach to Takeover Law and Regulatory Competition, 87 VA. L. REv. 111 (2001) [hereinafter Bebchuk \& Ferrell, A New Approach]; Lucian A. Bebchuk \& Allen Ferrell, Federal Intervention to Enhance Shareholder Choice, 87 VA. L. REv. 993 (2001) [hereinafter Bebchuk \& Ferrell, Federal Intervention]; Lucian A. Bebchuk \& Allen Ferrell, Federalism and Corporate Law: The Race to Protect Managers from Takeovers, 99 CoLum. L. Rev. 1168 (1999) [hereinafter Bebchuk \& Ferrell, Federalism and Corporate Law]; Sanjai Bhagat \& Roberta Romano, Event Studies and the Law-Part II: Empirical Studies of Corporate Law, 4 AM. L. \& ECoN. Rev. 380 (2002); Stephen Choi \& Andrew Guzman, Choice and Federal Intervention in Corporate Law, 87 VA. L. Rev. 961 (2001); Robert Daines, Does Delaware Law Improve Firm Value?, 62 J. FIN. Econ. 525 (2001); Jill E. Fisch, The Peculiar Role of the Delaware Couts in the Competition for Corporate Charters, 68 U. CIN. L. Rev. 1061 (2000); Marcel Kahan \& Ehud Kamar, Price Discrimination in the Market for Corporate Law, 86 CoRnell L. Rev. 1205 (2001); Ehud Kamar, A Regulatory Competition Theory of Indeterminacy in Corporate Law, 98 ColUM. L. Rev. 1908 (1998); Leo E. Strine, Jr., Delaware's Corporate-Law System: Is Corporate America Buying an Exquisite Jewel or Diamond in the Rough? A Response to Kahan \& Kamar's Price Discrimination in the Market for Corporate Law, 86 CORNELL L. REv. 1257 (2001).

4. Two events have recently brought these issues to the forefront. The first is the potentially sweeping decision of the European Court of Justice in the Centros case on which country's corporate law governs a firm. Case C-212/97, Centros Ltd. v. Erhverus - og Selskabstyrelsen, 2 C.M.L.R. 551 (1999). The second is the recent rejection of a proposed European Union directive on takeover regulation. See Proposal for a 13th European Parliament and Council Directive on Company Law Concerning Takeover Bids, at http://europa.eu.int/prelex/detail_dossier_real.cfm?CL=en\&DosId $=11887$ (last visited Nov. 12, 2002).

5. For further details on this position, see Winter, supra note 2; Romano, GeNius, supra note 2: EASTERBRoOK \& FisChel, THE ECONOMIC STRUCTURE, supra note 2.

6. Romano, Genius, supra note 2. 
The view that state competition works well rests on two propositions: (1) that states actively and vigorously compete for incorporations, and (2) that the ensuing competitive threat provides the dominant state of Delaware, as well as other states, with powerful incentives to provide value-enhancing rules. Even those skeptical of state competition have largely not questioned the first proposition-that states compete vigorously. The debate has thus focused on the second proposition-concerning the quality of incentives-and this Article will focus on it as well.

In questioning the quality of incentives provided by competition, critics have argued that the competitive threat might push states in undesirable directions with respect to some important corporate law issues. This view, to which we subscribe, holds that state competition does not work well with respect to some (but not all) important corporate law issues. ${ }^{7}$ On this view, state competition induces states to provide rules that managers, but not necessarily shareholders, favor with respect to corporate law issues that significantly affect managers' private benefits of control, such as rules governing takeovers. It has also been suggested that state competition leads Delaware to offer an excessively unpredictable body of law that creates unnecessary litigation. ${ }^{s}$

To shed light on this debate, researchers have undertaken a large number of empirical studies. The authors of these studies, as well as corporate law scholars who have used the studies in their own work, have generally interpreted the empirical findings as supporting the race-to-the-top view. Indeed, supporters of state competition have seized on these studies as strong-nay, decisive-evidence that state competition serves shareholder interests. For example, Roberta Romano has concluded that the findings of the empirical work "are compelling evidence that competition benefits shareholders." On a similar note, Frank Easterbrook and Daniel Fischel ,have stated: "Empirical studies confirm[ ] the force of competition... These findings fatally undermine [the 'race to the bottom'] position ....".10

7. See Bebchuk, supra note 2; Bebchuk \& Ferrell, Federalism and Corporate Law, supra note 3; Bebchuk \& Ferrell, A New Approach, supra note 3; OREN BAR-GILl ET AL., THE MARKET FOR Corporate Law (Harv. John M. Olin Center for L., Econ., \& Bus., Discussion Paper No. 377, 2002); cf. Cary, supra note 1.

8. See Kamar, supra note 3, at 1927-39; cf. Jonathan R. Macey \& Geoffrey P. Miller, Toward an Interest-Group Theory of Delaware Corporate Law, 65 TEx. L. REv. 469 (1987).

9. Roberta Romano, The Need for Competition in International Securities Regulation, 2 THEORETICAL INQUIRIES IN L. 1, 113 (2001), at http://www.bepress.com/til/default/vol2/iss $2 / a r t 1$. Professor Romano has expressed similar views in other papers. See Roberta Romano, Empowering Investors: A Market Approach to Securities Regulation, 107 YALE L.J. 2359, 2384 (1998) ("The empirical research on state competition undermines the race-for-the-bottom argument . ..."); Bhagat \& Romano, supra note 3, at 384 ("One certainly cannot read the event study literature and conclude that firms reincorporating are reducing their shareholders' wealth as [critics of the "race to the top" theory] contend[ ].").

10. EASTERBROOK \& FISCHEL, supra note 2, at 214-15. 
This Article challenges this assessment of the evidence. We argue that the conclusions supporters of state competition have drawn from the empirical evidence are unjustified. The existing evidence does not fatally undermine the criticisms of state competition, but rather leaves them unscathed. Further, evidence generated by a new empirical approach to evaluating state competition indicates that competition rewards and encourages the amassing of antitakeover statutes by states. This new evidence calls into question state-competition supporters' belief that state competition does not push states to adopt antitakeover statutes.

The skeptical account of state competition, which we will demonstrate is consistent with the empirical evidence, is as follows: Because managers have substantial influence over where companies are incorporated, a state that wishes to maximize the number of corporations chartered in it will have to take into account the interests of managers. As a result, state competition pushes states to give siguificant weight to managerial interests.

Of course, catering to managerial interests is only problematic when the interests of shareholders and managers substantially diverge. Thus, in our view, state competition will likely fail shareholders with respect to issues that are "significantly redistributive" in that they involve a siguificant trade-off between important managerial and shareholder interests. One area where such a divergence of interests is likely to be particularly acute is takeover regulation. Managers interested in preserving their jobs and private benefits of control will tend to favor restrictive takeover rules, whatever the costs to shareholders.

Does the existing empirical evidence contradict this skeptical account, as so many claim? Part I examines the significant body of empirical work that has sought to determine the effects of Delaware mcorporation on shareholder value. This work includes a recent cross-sectional study suggesting that shareholder value is higher for Delaware companies than for non-Delaware companies as well as reincorporation event studies indicating that reincorporations to Delaware were accompanied by increases in stock price.

A close examination of the findings of both types of studies shows that, taken as a whole, they do not establish a robust and significant correlation between Delaware incorporation and higher shareholder wealth. Furthermore, even assuming that a robust and significant correlation between Delaware incorporation and somewhat higher shareholder value were present, supporters of state competition have failed to distingnish satisfactorily between correlation and causation. The correlation of Delaware incorporation and higher stock value would not necessarily imply causation of higher stock value by Delaware incorporation. The selection of firms that incorporate in Delaware, either initially or mid-stream, is not random. 
Firms electing to incorporate in Delaware and firms not making such elections must differ in some way that accounts for their different incorporation decisions. Any stock price effects correlated with Delaware incorporation may very well be due not to the direct effects of Delaware incorporation but rather to these underlying differences among firms. Indeed, we show that there is evidence that selection effects are likely to be very much at work and that inferences about the relative value of Delaware law cannot be reliably made from existing findings on correlations between Delaware incorporation and shareholder value.

Although we conclude in Part I that the existing evidence fails to demonstrate that Delaware mcorporation increases shareholder value, we do believe that it is reasonable to assume that Delaware incorporation on average benefits investors, even if in a rather sinall and limited way. However, as Part II explains, a inarginal superiority of Delaware incorporation for shareholder value does not imply that state competition (as currently structured) benefits investors. Indeed, the presence of such a marginal superiority would be consistent with our skeptical account of state competition. ${ }^{11}$

On our view, the incentive to cater to managerial interests, and in particular to protect managers excessively from takeovers, exists in all states that wish to attract incorporations. Consequently, all such states will be pushed towards privileging managers' interests over shareholders' interests when the two conflict. In such an equilibrium, Delaware incorporation might still provide some benefits to shareholders due to Delaware's well developed legal infrastructure and to network externalities. Nevertheless, the overall corporate regimes that states adopt would be adversely shaped by state competition.

The critical question to resolve, as Part II will emphasize, is whether the existing state competition equilibrium is superior to the set of corporate rules that would prevail in the quite different equilibrium that would obtain in the absence of the current form of state competition. This question should not be confused, as supporters of state competition seem to have done, with the question of whether Delaware is somewhat better than other states in the existing state competition equilibrium.

Part III turns froin these general considerations to the concrete case of state takeover regulation and what it can tell us about how state competition works in an important area of corporate law. State takeover regulation presents state coinpetition supporters with a dilemma. The dilemma stems from the fact that many state competition supporters believe that existing state takeover law restricts corporate takeovers excessively. Supporters have therefore been forced to reconcile this belief with their view that state

11. This point is formally demonstrated in a model developed in OREN BAR-GILL ET AL., supra note 7. 
competition produces desirable corporate law. To this end, they have made empirical claims that state competition has not contributed to the proliferation of antitakeover statutes but rather rewarded those states that have been comparatively moderate. Delaware, by far the most successful state in the incorporation marketplace, is usually cited as the paradigm of a state with a "moderate" takeover regime.

Part III shows, however, that the empirical claims made by supporters of state competition fail to establish that state competition rewards moderation in the provision of antitakeover protections. First, although Delaware does not go as far as some states that have adopted extreme antitakeover statutes, it is far from clear that Delaware is more moderate than most states in its antitakeover stance. Second, the studies of states that have adopted extreme antitakeover statutes (Massachusetts, ${ }^{12}$ Ohio, ${ }^{13}$ and Pennsylvania ${ }^{14}$ ) do indicate that the adoption of these statutes has been detrimental to shareholder value, but they do not show that the incorporation marketplace has penalized these three states by reducing the number of incorporations in them. Whether these states have in fact been harmed or benefited by their adoption of extreme antitakeover protections in the incorporation marketplace is a question Part IV addresses.

Part IV proposes a promising new approach to the empirical investigation of state competition. We argue that researchers and corporate law scholars should seek to identify the determinants of firms' incorporation choices. Whereas prior work has largely taken incorporation choices as given, and has sought to identify how those incorporation decisions were associated with shareholder value, the proposed approach attempts to identify the factors that determine incorporation decisions in the first place. Furthermore, whereas prior work has largely ignored the considerable variance among states other than Delaware with respect to success in the incorporation market, we argue that this variance can be used to examine how differences in state corporate law regimes affect firms' incorporation decisions.

Part IV presents some summary statistics and basic cross-state comparisons that illustrate the value of this approach. Part IV also summarizes and discusses the findings of a separate study by two of us (the

12. Mass. Gen. Laws AnN. ch. 156B, $\S 50 \mathrm{~A}$ (2002); see also Grant Gartman, State ANTITAKEOVER Laws: MassachusetTs-2 To MassachusetTs-3 (Investor Responsibility Research Center 2000).

13. Ohio Rev. Code AnN. $§ 1707.043$ (Anderson 2002); see Gartman, supra note 12, Ohio-2 то Оніо-3.

14. 15 Pa. Cons. Stat. $\$ \S 2571-2575$ (2002); see Gartman, supra note 12 , Pennsylvania-2 to Pennsylvania-3. 
Incorporation Study) which carried out a full empirical analysis based on this approach. ${ }^{15}$

As will be described in more detail below, the analysis of incorporation decisions reveals that the competition for incorporations does in fact reward the amassing of antitakeover protections. At one end of the spectrum, states with no antitakeover statutes, such as California, do quite poorly, retaining a relatively small fraction of the companies headquartered in them and attracting a small or even negligible number of out-of-state companies. At the other end of the spectrum, states that are quite successful on these two dimensions are typically ones that have amassed most if not all of the standard antitakeover statutes. In general, the success of a state in the market for incorporations increases as its level of antitakeover protection increases (controlling, of course, for company characteristics and for the characteristics of states other than their takeover laws).

Interestingly, the evidence does not show that the incorporation market penalizes states that have adopted extreme antitakeover statutes, as Massachusetts, Ohio, and Pennsylvania have done. Although the adoption of these statutes was umiversally criticized and accompanied by a significant reduction in the stock value of corporations incorporated in these states, these states have not suffered in the incorporation market. We do not doubt that there is some level of extreme antitakeover protection that would "over-do it" and make a state adopting it less attractive to incorporators. However, in contrast to the beliefs of state competition supporters, this level has apparently not been reached by Massachusetts, Ohio, and Pennsylvania, the three states blacklisted by scholars as extrenie.

The study of the determinants of incorporation decisions can thus shed a more systematic light on the connection between state competition and takeover rules. Competition appears to reward, and thus encourage, the amassing of antitakeover statutes. It is therefore difficult to maintain, as many supporters of state competition have done, both that (1) state coinpetition generally rewards the provision of rules that enhance shareholder value, and (2) amassing antitakeover protections will restrict takeovers excessively and hurt shareholder value. At least one of these two propositions is in need of revision.

The Article concludes that, in contrast to the strongly held beliefs of race-to-the-top scholars, the evidence is consistent with, and in certain ways supports, the skeptical view of how state competition, as currently structured, performs with respect to iniportant corporate law subjects. This

15. See Lucian Bebchuk \& Alma Cohen, Firms' Decisions Where to Incorporate, 46 J.L. \& EcoN. (forthcoming Oct. 2003). For another contemporaneous study which applies this approach, and whose results we discuss, see Guhan Subramanian, The Influence of Antitakeover Statutes on Incorporation Choice: Evidence on the "Race" Debate and Antitakeover Overreaching, 150 U. PA. L. REv. 1795 (2002). 
conclusion has significant implications for the ongoing debates regarding state competition, corporate governance, and state takeover law.

Before proceeding, we wish to note an additional reason-which is outside the scope of this Article's analysis-for questioning the empirical basis of the view supporting state competition. As noted, whereas we focus here on the proposition that competition provides desirable incentives, another key proposition underlying the race-to-the-top view is that states vigorously compete for corporate charters. In a companion work, we put forward empirical evidence questioning this premise as well. The Incorporation Study indicates that competition is highly imperfect in that Delaware faces scant competition in the market for out-of-state incorporations; firms largely incorporate either in Delaware or in the state of their headquarters. ${ }^{16}$ Building on this finding, a companion work by Assaf Hamdani and one of us provides evidence that Delaware's dominance of the incorporation market is stronger and more secure than has been recognized, and it then discusses how this feature of the incorporation market casts doubt on the extent to which this market can be relied on to produce rules that enhance shareholder value. ${ }^{17}$ This work complements the analysis of this Article and reinforces its message - that the existing evidence does not support the views of state-competition advocates.

\section{Does Delaware InCorporation Increase Shareholder Value?}

Researchers have tried to test whether Delaware corporate law is superior by identifying how, compared with firms incorporated in other states, incorporation in Delaware affects stock price, Tobin's $Q,{ }^{18}$ or some other metric associated with shareholder wealth. We begin our examination of these studies by discussing, in Part I.A, Robert Daines's influential paper measuring and comparing the Tobin's $Q$ of Delaware and nonDelaware firms. Part I.B will then look at reincorporation event studies, which measure stock price reaction to a firm's reincorporation from one state to another. We will show that the findings of some of these studies are weaker and less conclusive than has been generally recognized. More importantly, both the reincorporation event studies and Daines's Tobim's Q study fail to establish that their findings of increased value for Delaware firms, whatever the metric being used, should be attributed to Delaware's provision of a superior corporate law system. It is crucial in assessing these

16. See Bebchuck \& Cohen, supra note 15 .

17. See Lucian A. Bebchuk \& Assaf Hamdani, Vigorous Race or Leisurely Walk: Reconsidering the Debate on State Competition in Corporate Law, 111 Yale L.J. (forthcoming Dec. 2002). An empirical analysis that complements this work is offered by Marcel Kahan and Ehud Kamar, The Myth of State Competition in Corporate Law, 55 STAN. L. REv. (forthcoming 2002).

18. See Richard A. Brealey \& Stewart C. Myers, Principles of Corporate Finance 77576 (5th ed. 1996) (explaining Tobin's Q). 
studies to remember that incorporation and reincorporation decisions are not random; there is thus no good basis for inferring that the measured differences in shareholder wealth are due to differences im corporate law quality as opposed to whatever influences firms' (re)mcorporation decisions.

\section{A. Tobin's $Q$ Differences Between Delaware and Non-Delaware Corporations}

Recognizing the limitations of reincorporation event studies, which we will discuss in the next Section, Robert Daines sought to test the effect of Delaware imcorporation on shareholder wealth im a different way. In a recent but already influential study, he compared Delaware and nonDelaware companies in terms of Tobin's Q. ${ }^{19}$ Tobin's $Q$, which is the ratio between a firm's market value and its book value, is a widely used measure of how valuable a firm's assets are in relation to their replacement cost. Looking at the aggregate data from 1981 to 1996, Daines found that Delaware companies had a higher Tobin's $Q$ even after controlling for a variety of factors. He inferred from this finding that Delaware law accounts for the higher Tobin's $Q$ and, therefore, acts to increase shareholder value.

Daines's findings havc received a great deal of attention ${ }^{20}$ and have been put forward by supporters of state competition as strong evidence for their view. ${ }^{21}$ As explained below, however, subsequent work has shown that the reported correlation between Tobin's $Q$ and Delaware incorporation no longer exists. Furthermore, the evidence about the existence of such a correlation in the past does not tell us whether such a correlation was due to a selection effect rather than to the beneficial effects of Delaware incorporation.

\section{The Current Nonexistence of Correlation}

Work done subsequent to Daines's study indicates that the reported correlation no longer exists. The Incorporation Study, examining data from the end of 1999, found that there was no correlation between Delaware incorporation and higher Tobin's Q at the end of 1999. ${ }^{22}$ Another recent study, by Gompers, 1shii, and Metrick, using a set of controls that includes firm-level corporate governance arrangements, found that during the $1990 \mathrm{~s}$

19. See Daines, supra note 3 .

20. See, e.g., Steven Lipin, Firms Incorporated in Delaware Are Valued More by Investors, WALI ST. J., Feb. 28, 2000, at C21.

21. See, e.g., Jonathan R. Macey, Displacing Delaware: Can the Feds Do a Better Job Than the States in Regulating Takeovers? 57 Bus. LAw. 1025 (2002) (relying on Daines's findings to oppose a proposal by Bebchuk and Ferrell for choice-enhancing federal intervention).

22. See Bebchuck \& Cohen, supra note 15. 
Delaware incorporation was, on average, associated with a lower Tobin's Q. ${ }^{23}$

Furthermore, in a working paper focusing on the correlation between Tobin's Q and Delaware incorporation, Guhan Subramanian finds that no correlation between a higher Tobin's $Q$ and Delaware incorporation existed in any of the years 1996-2001. ${ }^{24}$ Subramanian improves upon Daines's testing methodology in several ways and provides a thorough and careful testing of the Tobin's Q question. While his results confirm the existence of a correlation between Tobin's $Q$ and Delaware incorporation during the years 1991-1996, they indicate that such correlation does not exist in any of the years after 1996, which is when Daines's study ended.

Interestingly, the single-year regressions in Daines's study indicate that a positive correlation between higher Tobin's Q and Delaware incorporation did not exist in five years (I982, 1987, 1989, 1991, 1995) during the period studied; ${ }^{25}$ in an additional year (1996), the statistical significance of the correlation was only at a $90 \%$ level. ${ }^{26}$ Subramanian reexamines three of these years (1991, 1995, and 1996) and finds that the correlation did exist in two of them but did not for the other one. ${ }^{27}$

In any event, whether or not the correlation existed in all of the years during the period covered by Daines's study, for our purposes the crucial point is that such a correlation does not exist at the present time. This fact should give supporters of state competition some pause. If the existence of the correlation was viewed by them as an indication that competition works well, shouldn't the nonexistence of such a correlation now lead to doubts as to whether competition is working as well at the present time?

\section{The Fluctuations of the "Delaware Effect"}

An assessment of Daines's findings should take into account the fluctuations in the size of the Delaware effect. An examination of his results indicates that the magnitude of the correlation varied greatly from year to year. For instance, Daines's regressions indicate that Delaware companies had a Tobin's Q in 1986 that was $12 \%$ higher (at a 99\% confidence level) than that of non-Delaware companies. In the subsequent year, 1987,

23. See Paul A. Gompers et al., Corporate Governance and Equity Prices (Nat'l Bureau of Econ. Res., Working Paper No. 8449, 2001). Specifically, they find that Delaware incorporation tended to be positively correlated at the beginning of the studied period and negative toward the end, with an average coefficient that was negative and statistically significant. $I d$.

24. See Guhan Subramanian, The Disappearing Delaware Effect (Sept. 2002) (unpublished working paper, on file with authors).

25. See Daines, Delaware Law, supra note 3, at 535.

26. The same basic picture emerges if one uses Tobin's $Q$ unadjusted by industry. There were four years in which there was no statistically significant correlation between Delaware incorporation and (an unadjusted) Tobin's $Q$ and one additional year in which the statistical significance of the correlation was only at a $90 \%$ level. Daines, supra note 3.

27. See Subramanian, supra note 24. 
however, the increase in Tobin's Q associated with Delaware incorporation was only $5 \%$, which was statistically insignificant from zero. To take another example, in 1991 the increase in Tobin's Q associated with Delaware incorporation was $4 \%$, also not statistically significant from zero, while in 1992 , that figure suddenly increased to $12 \%$ (at a $99 \%$ confidence level). ${ }^{28}$

Such large fluctuations from year to year are deeply puzzling if one takes the view that differences in value between Delaware and nonDelaware companies are the result of the benefits of Delaware law. For Daines's attribution of the differences in Tobin's $Q$ to the superiority of Delaware's corporate law regime to be plausible, there must have been ground-breaking legal changes in Delaware corporate law that occurred during these years that can account for these fluctuations. It is hard to imagine what these dramatic changes could have been. Whatever the beneflts of Delaware's legal regime and thus of Delaware incorporation, they must be more stable than that.

In his working paper recreating Daines's analysis, using different specifications for some key variables, Subramanian obtains results im which the Delaware effect does not fluctuate wildly from year to year but still changes significantly over time. ${ }^{29} \mathrm{He}$ finds that, while Delaware firms were worth 2-3\% more during the period from 1991 to 1996 (3\% in 19911993 and $2 \%$ in 1994-1996), there was no statistically siguificant difference between Delaware and non-Delaware firms from 1997 on. Subramanian seeks to explain the change in the value of Delaware firms between 1996 and 1997 by a growing perception in the market, caused by three cases in which Delaware firms fended off hostile bidders, that Delaware would allow target management to "just say no" to hostile bids. Subramanian acknowledges that the permissibility of "just say no" was largely established by Delaware law several years earlier and that the bidders in the three cases on which he relies did not even try to get the Delaware courts to order poison pill redemption. But he conjectures that these three cases might have made the permissibility of "just say no" under Delaware law more salient. It is far from clear, however, that such a saliency story can account for a $2 \%$ decline in the value of Delaware firms from 1996 to 1997.

The fluctuations in the Delaware effect, whether from year to year or from period to period, might be due to a selection effect. According to this explanation, Delaware companies differ significantly from non-Delaware firms in some underlying way-they are of a different "type." And it is not unusual in the stock market for the relative pricing of firms of different types to fluctuate considerably from year to year. This possibility brings us to the general problem of selection.

29. See Subramanian, supra note 24. 


\section{The Problem of Selection}

There might be some who, upon finding that the correlation between Tobin's $Q$ and Delaware incorporation no longer exists, might want to move on to other pieces of the empirical evidence. It is worthwhile, however, to examine whether the existence of correlation in some past periods (even if not now) indicates that Delaware incorporation did produce significant increases in value for shareholders. To draw such an inference, it would be necessary to determine whether the relationship between Delaware incorporation and a higher Tobin's Q (or a positive abnormal price reaction in the case of reincorporation event studies) is one of causation or mere correlation. In other words, did Delaware law cause Delaware firms to have a higher Tobin's Q or did companies choosing to incorporate in Delaware tend to have a higher Tobin's Q?

If incorporation and reincorporation decisions were random, and if we could therefore safely assume that Delaware and non-Delaware firms were identical other than in their state of incorporation, differences in Tobin's Q would arguably be attributable to Delaware's superior corporate law regime. But if incorporation decisions were not random, then the differences in Tobin's Q could have resulted from the systematic differences between firms that incorporated in Delaware and those that did not. Below we discuss why incorporation decisions should not be regarded as random.

\section{a. Selection Follows from the Very Presence of a Delaware Wealth Effect}

If there were any period in which Delaware incorporation could bring about an increase in shareholder value, it would follow that Delaware and non-Delaware firms differed in systematic ways other than in their state of incorporation. Consider a period in which a move to Delaware could have produced, say, a $3 \%$ or $5 \%$ increase in value for companies incorporated in other states. ${ }^{30}$ Why did some firms choose to leave so much money on the table, money they could easily have collected by simply (re)incorporating in Delaware? There must have been something different about these firms. The difference might have been in managerial quality, or agency costs, or firm strategy. Whatever it was, this difference must have been significant enough to cause non-reincorporating firms to forgo an easy and significant increase in firm value. Once differences between Delaware and nonDelaware firms are admitted, however, there is a real possibility that they, rather than the purported benefits of Delaware incorporation, account for whatever differences in value existed, at any given point in time, between Delaware and non-Delaware companies.

30. Five percent is the estimate provided by Daines's study for the value-added of Delaware law given the pooled sample estimates. See Daines, supra note 3, at 535 tbl. 3. Subramanian estimates that Delaware firms were worth 2\%-3\% more during the period 1991-1996. Subramanian, supra note 24. 
While Daines's study makes an impressive effort to control for as many parameters as possible, including type of business and firm size, it nonetheless remains true that if in a group of seemingly identical firms, some firms imcorporate im Delaware and others do not, there must be omitted variables that produce this differential behavior. This is all the more true if it is supposed that one choice produces a substantial increase in firm value and the other does not.

The presence of such variables is clearly suggested by the results of the Incorporation Study. ${ }^{31}$ Using the Compustat database that Daines also used, this study sought to identify which characteristics make companies more or less likely to incorporate in Delaware. It found, for example, that larger and netver companies are more likely to incorporate in Delaware. For our purposes, however, the crucial point is that the study's regressions, controlling for various company characteristics (which Dames also controlled for) had an explanatory power of only $13 \%$ for the decision whether or not to incorporate in Delaware. ${ }^{32}$ This finding clearly suggests the importance of omitted variables in explaining why some firms but not others choose Delaware incorporation. ${ }^{33}$

\section{b. Understanding Selection}

There are various explanations that could account for why firms with the same Compustat data characteristics make different incorporation and reincorporation decisions. Consider, for example, the following scenario. ${ }^{34}$ Law firms centered in national financial centers such as New York City might tend to prefer Delaware incorporation. And companies that use such

31. Bebchuck \& Cohen, supra note 15.

32. Id.

33. It is worth noting another interesting attempt by Daines to isolate his findings from the selection effect. He estimates the difference in Tobin's Q only between mature Delaware and mature non-Delaware firms on the theory that a firm's current valuation is unrelated to its valuation years ago. He also estimates the difference in Tobin's $Q$ between Delaware and non-Delaware firms while controlling for the prestige of the firm's underwriter at the time of its initial public offering ("IPO"), assuming that this prestige is correlated with the firm's quality and value. These tests also show a correlation between Delaware incorporation and a higher Tobin's Q.

But these tests do not solve the selection effect problem for two reasons. First, the finding that otherwise identical firms, as indicated by their choice of an underwriter or unaturity, nnake different choices on whether or not to incorporate in Delaware still raises the same type of questions. If the firms are really identical, one must ask what accounts for the difference in incorporation choices, unless one believes that incorporation choices are random. And why are underwriters with similar prestige sometines associated with Delaware incorporations and soinetimes with non-Delaware incorporations, which are value-reducing?

Second, these tests cannot address selection effects that occur after incorporation. We know that some selection among firms must be occurring because of the non-random nature of reincorporation decisions. Controlling for decisions made at the time of incorporation does not control for the decisions that have been made since that time with respect to whether or not to reincorporate. The current state of incorporation of the firms whose Tobin's Qs are being measured will reflect these post-incorporation decisions.

34. This scenario is suggested in Bebchuk \& Ferrell, A New Approach, supra note 3, at 137-38. 
law firms for their counsel might be persuaded or influenced to incorporate in Delaware. It is possible that these companies may be more likely to have sophisticated and ambitious managers or have some other quality that operates to increase firm value. Of course, this scenario, based on managerial heterogeneity, is only one of many possible stories that an examination of the selection issue should consider. The critical point is that the different incorporation choices of firms with the same basic financial featuressome of which incorporate in Delaware and some of which do not-are bound to reflect some other differences between them, and the latter might account for whatever differences in shareholder value exist between Delaware and non-Delaware firms.

Discovering what influences companies' incorporation decisions is an area in need of empirical work. Until such studies are available and we know a great deal more about how firms make incorporation decisions, the attribution of differences in firm value to differences in corporate law regimes will remain questionable.

\section{B. Event Studies of Reincorporations}

A number of studies have examined stock price reaction to changes in a firm's state of incorporation. The overwhelming majority of the firms examined by these studies, as is true with reincorporating firms in general, reincorporate to Delaware. ${ }^{35}$ The reincorporation studies are by far the most commonly cited evidence for the proposition that Delaware corporate law increases shareholder wealth. Such studies, for instance, provided much of the basis for the views of Professors Easterbrook, Fischel, and Romano quoted earlier. ${ }^{36}$

What conclusions should we draw from these reincorporation studies? Part I.B.1 will emphasize that in answering this question one should bear in mind the flaws in some of these event studies and the fact that the documented positive abnormal returns associated with reincorporations are, on the whole, quite modest. Part I.B.2 will then argue that there is no firm basis for attributing these modest positive abnormal returns to the superiority of Delaware's corporate law regime.

\section{The Abnormal Returns Findings: Questions of Robustness and Magnitude}

There have been eight reincorporation event studies. Overall, the picture that emerges is one of modest gains accompanying reincorporation. Six of the eight studies documented positive abnormal stock returns

35. See Bhagat \& Romano, supra note 3, at 383; Romano, Law as a Product, supra note 2, at 244.

36. See supra Introduction. 
associated with the reincorporating firms in the sample. ${ }^{37}$ The remaining two found negative abnormal returns associated with reincorporations: One found negative returns associated with the entire sample, ${ }^{38}$ while the other found negative returns associated with a subgroup of the reincorporating firms. ${ }^{39}$ Pooling the results from all eight studies, the weighted average price reaction to reincorporation is $+1.28 \%{ }^{40}$ Even accepting this finding at face value, the positive abnormal return attributable to Delaware's superior corporate law regime is rather small. Before drawing any firm conclusions, however, it is first worth taking a closer look at these event studies.

The two earliest reincorporation event studies used problematic methodologies that were subsequently viewed to be unreliable. ${ }^{41}$ Six subsequent studies used more standard and reliable methodologies. These six studies,

37. See Michael Bradley \& Cindy A. Schipani, The Relevance of the Duty of Care Standard in Corporate Governance, 75 IowA L. REv. 1 (1989); Peter Dodd \& Richard Leftwich, The Market for Corporate Charters: "Unhealthy Competition" Versus Federal Regulation, 53 J. Bus. 259 (1980); Allen Hyman, The Deloware Controversy-The Legal Debate, 4 J. CoRP. LAw 368 (1979); Jeffrey Netter \& Annette Poulscn, State Corporation Laws and Shareholders: The Recent Experience, 18 Fin. MGMr. 29 (1989); Romano, Law as a Product, supra note 2; Jianghong Wang, Performance of Reincorporating Firms (1995) (unpublished manuscript, on file with authors).

38. See Randail A. Heron \& Wilbur G. Lewellen, An Empirical Analysis of the Reincorporation Decision, 33 J. Fin. \& Quantitative Analysis 549 (1998).

39. See Pamela Petcrson, Reincorporation Motives and Shareholder Wealth, 23 FIN. Rev. 151 (1988).

40. Returns are weighted by their sample size. In taking pooled average price reactions, we follow John C. Coates IV, Takeover Defenses in the Shadow of the Pill: A Critique of the Scientific Evidence, 79 TEx. L. Rev. 271, 283 (2000), and Michael C. Jensen \& Richard S. Ruback, The Market for Corporate Control: The Scientific Evidence, 11 J. FIN. EcoN. 5, 12-13 (1980).

41. In the first study, Allen Hyman found positive abnormal returns for reincorporating firms for four of the five trading days prior to the public announcement of reincorporation. Hyman, supra note 37. But this finding does not tell us whether the positive abnormal returns were associated with the reincorporation announcement itself, which is the relevant date. Whether statistically abnormal returns for the sample occurred over a period spanning the five days before and after the announcement day itself is unreported. The study does not tell us whether there were positive abnormal returns associated with the period spanning one day immediately before and after the aunouncement date, a commonly used tine-frame for reincorporation studies. These concerns are heightened by the fact that abnormal returns were determined by reference to the performance of Standard \& Poor's S\&P 500 index, a somewhat unorthodox, and unreliable, methodology.

The second reincorporation event study, by Peter Dodd and Richard Leftwich, examined a sample of 140 publicly traded companies that reincorporated between 1927 and 1977. Dodd \& Leftwich, supra note 37. The study did find statistically significant positive abnormal returns, but it used an interval of two years before the reincorporation date. Such an extended period sheds little light on the effect of reincorporation. It is generally true that using an interval of a few days or weeks around an event, rather than just the day of the event itself, can still do a good job of capturing the effects of the event. However, this generalism is not true for a two-year interval. See, e.g., Brad M. Barber \& John D. Lyon, Detecting Long-Run Abnormal Stock Returns: The Empirical Power and Specification of Test Statistics, 43 J. FIN. EcoN. 341, 342-43 (1997) (also finding that long-run tests are misspecified and identifying new listing bias, rebalancing bias, and skewness bias as reasons); S.P. Kothari \& Jerold B. Wamer, Measuring Long-Horizon Security Price Performance, 43 J. Fin. Econ. 301, 301, 337 (1997) (finding that tests of multi-year abnormal returns around firm-specific events are "severely misspecified" and concluding that "the interpretation of long-horizon tests requires extreme caution"). 
summarized in the table below, present a rather mixed picture. ${ }^{42}$ Roberta Romano's study, the earliest and most influential of the six, found a positive abnormal return of $4.18 \%{ }^{43}$ However, three of the subsequent five studies found abnormal returns in the vicinity of $1 \%$, and two of the subsequent five studies, including the most recent event study which used the largest sample size, did not find an abnormal return that differed from zero in a statistically significant way.

Authors

Abnormal Return

Sample Size

\begin{tabular}{|l|c|c|}
\hline Romano (1985) & $4.18 \%$ & 150 \\
\hline Peterson (1988) & $.27 \%$ & 30 \\
\hline Bradley \& Schipani (1989) & $1.04 \%$ & 32 \\
\hline Netter \& Poulsen (1989) & $.93 \%$ & 36 \\
\hline Wang (1995) & $.97 \%$ & 145 \\
\hline Heron \& Lewellen (1998) & $-.15 \%$ & 294 \\
\hline
\end{tabular}

Thus, a $1 \%$ positive abnormal return is probably as fair a measure as any if one were inclined to rely on these event studies to measure the effect on stock price of reincorporation to a superior corporate law regime. ${ }^{44}$ Accordingly, even if the positive abnormal stock price reaction is entirely due to the benefits of Delaware incorporation, these benefits appear to be rather modest. ${ }^{45}$ For instance, the adoption of confidential voting, which is usually not considered a significant change, has a reported positive abnormal return of approximately $1 \% .{ }^{46}$ But should one attribute the entire positive abnormal return found in these event studies to the superiority of Delaware incorporation?

\section{The Problem of Confounding Events \\ a. Confounding Events}

If the subset of firms reincorporating at any point in time were a random selection from the universe of all corporations, it would follow that unaccounted for increases in a reincorporating firm's stock price on the date the news of reincorporation reached the market could reasonably be attributed to Delaware's superior corporate law. The randomness of the

42. See Bradley \& Schipani, supra note 37; Heron \& Lewellen, supra note 38; Netter \& Poulsen, supra note 37; Peterson, supra note 39; Romano, Law as a Product, supra note 2; Wang, supra note 37.

43. See Romano, Law as a Product, supra note 2.

44. The pooled weighted average abnormal return of these six studies is $1.16 \%$.

45. We do recognize, of course, that a $1 \%$ increase in firm value can still be quite meaningful in terms of the dollars at stake. We point out the size of the abnormal return merely to place it in perspective.

46. Coates, supra note 40 , at 284 (pointing out that the positive abnormal return of adopting confidential voting is $.9234 \%$ ). 
selection would help ensure that firm-specific characteristics were not affecting stock prices.

However, there is good reason to believe (as was also the case when considering Daines's Tobin's Q study) that reincorporation decisions are not random, but rather are associated with or produced by specific events or occurrences, a phenomenon we will refer to as "confounding events." As a result, any findings of positive abnormal returns could well be the result not of investors' anticipation of moving to a better legal regime but rather of investors' reactions to these confounding events. The need to disentangle various effects is a generic problem that arises with the use of event studies in the field of corporate law, but its importance varies with the context. ${ }^{47}$ In the context of corporate reincorporations, the presence of confounding events is an issue that must be confronted because reincorporation decisions are clearly not random. Only some firms elect to reincorporate, and they choose to do so at a particular point in time. Thus, some event, perhaps the receipt of new information concerning the corporation or a new firm strategy, must underlie the decision of the managers of a minority of coinpanies to pursue reincorporation to a particular state at a specific point in time. Investors could very well revise their estimates of a company's value in light of such an event, if the event is observable, or in light of the inference that such an event might have occurred, if the event is not observable. Either way, reincorporations are likely to be accompanied by investors revising their estimates of the value of reincorporating companies for reasons that have nothing to do with differences in legal regimes.

Indeed, a close examination of the reincorporation event studies confirms that confounding events have a considerable impact on documented returns. Most of the studies indicate that reincorporations are the product of significant selection effects and were accompamed by certain events (which could have caused revised valuation) or were followed by certam events (and thus could have been viewed by investors as signals that such events might indeed follow). For example, in a well known study, Romano found that "most reincorporations preceded or coincided with a series of distinct and identifiable transactions," explanation of the reincorporation phenomenon is that corporations planning to engage in specific activities consider the choice of domicile important." ${ }^{249}$ Such findings are consistent with the view that reincorporations are not random, and that the returns accompanying remcorporations reflect

47. For instance, an important issue in corporate finance is the effectiveness of event studies in identifying the underlying sources of the gains that occur as a result of corporate mergers. See Gregor Andrade et al., New Evidence and Perspectives on Mergers, 15 J. Econ. PERSP. 103, 117 (2001).

48. See Roinano, Law as a Product, supra note 2, at 250 . Professor Romano reports that $72 \%$ of reincorporations between 1960 and 1982 were associated either with a public offering of stock, mergers, or adoption of antitakeover defenses. RoMaNo, GeNIUs, supra note 2, at 33 .

49. Romano, Law as a Product, supra note 2, at 261. 
investors' reactions to events that partly coincide with, and partly might be inferred from, the reincorporation decisions.

Of Romano's sample of 150 reincorporations, sixty-three were associated with an active merger and acquisitions program by the firms in question. ${ }^{50}$ Such programs are known to be associated with positive abnormal returns. ${ }^{51}$ Below we will discuss two other types of confounding events stories that seem plausible in light of the evidence. Each one of them could well have been present in some significant fraction of reincorporations and could explain why, even if firms do not on average benefit from moving to Delaware's legal regime, reincorporations were accompanied by increases in company value. The following list of types of confounding events is meant to be illustrative, not exhaustive.

\section{b. Scheduling Reincorporation Votes in Relatively Good Times}

Managers interested in reincorporation might well prefer bringing reincorporation proposals to a shareholder vote when things are going well, or at least not poorly, for the company. Managers are more likely to receive shareholder approval for a proposal if shareholders are content with the company's overall performance. Managers, who have a great deal of flexibility in terms of when a reincorporation proposal will be brought before shareholders, can orchestrate, at least to a significant extent, shareholder votes to coincide with good times.

Thus, it might be that, on average, managers bring reincorporation proposals to shareholders when contemporaneous news about the company's performance, or news expected to be released by the time of the vote, is better than average. Indeed, to produce an average positive stock price effect, it would be enough merely that managers avoid pursuing reincorporations at times when particularly bad news about the company is revealed. In short, according to this explanation, reincorporations may generally be accompanied by an upward revision in investors' valuations because investors on average receive or expect to receive better than average news.

The story that managers time reincorporation votes to take place when things are going better than average sits well with a pattern established by the reincorporation event studies. As Michael Bradley and Cindy Schipani explain, "firms choose to reincorporate in Delaware after they have experienced an abnormal run-up in their stock price. ${ }^{.52}$ Consistent with this observation, the Dodd and Leftwich reincorporation event study found, both for the entire sample of reincorporating firms as well as for the group

50. Id. at 268 .

51. See Katherine Schipper \& Rex Thompson, Evidence on the Capitalized Value of Merger Activity for Acquiring Firms, 11 J. Fin. ECoN. 85 (1983).

52. Bradley \& Schipani, supra note 37, at 67 . 
of firms for which they had accurate reincorporation announcement dates, that most of the abnormal returns experienced by reincorporating firms occurred well before the event date. ${ }^{53}$ The same finding was subsequently reproduced in both Romano's 1985 event study ${ }^{54}$ and Bradley and Schipani's 1989 event study. ${ }^{55}$ This pattern is consistent with the view that the reincorporation event studies lump together abnormal returns that lead to or influence the timing of the reincorporation decision (and which could well continue to be present at the time of the reincorporation announcement) with abnormal returns that should be attributed to the reincorporation announcement itself, shorn of any confounding events.

Furthermore, the Heron and Lewellen reincorporation event study reports that a significant number of reincorporations in the study's raw data set coincided with substantial corporate events such as dividend increases. ${ }^{56}$ Whereas Heron and Lewellen excluded these reincorporations froin the sample they studied, other studies ${ }^{57}$ did not similarly attempt to exclude companies that increased their dividends (or had other coincident events) at the same time that they announced their plan to reincorporate, which might explain why these studies found higher positive abnormal returns associated with reincorporation than did the Heron and Lewellen study.

\section{c. Increased Likelihood of Takeover}

A second plausible confounding events story centers on takeover defenses. As the reincorporation events studies indicate, a significant number of reincorporations are motivated by antitakeover considerations. Reincorporating companies often candidly admit that antitakeover considerations are a motive for seeking reincorporation..$^{58}$ When investors suspect or are told that a company is moving for such reasons, they will adjust their valuations of the company to reflect not only (1) the direct effect of the company being subject to a different state takeover regime, but also (2) the increased probability, inferred from the managers' focus on antitakeover considerations, of the company being a target.

The second factor, the increased probability of a takeover, is generally received as good news by investors and can be expected to have a positive effect on stock prices. Thus, the presence of this factor, according to this explanation, implies that the reported positive abnormal returns documented in reincorporation event studies represent an upward biased

53. Dodd \& Leftwich, supra note 37, at 272-78.

54. Romano, Lav as a Product, supra note 2, at 269-71.

55. Bradley \& Schipani, supra note 37, at 66-67.

56. Heron \& Lewellen, supra note 38 , at 553.

57. See, e.g., Hyman, supra note 37.

58. See, e.g., Heron \& Lewellen, supra note 38, at 553; Romano, Law as a Product, supra note 2, at $225,249-61$. 
estimate of the effect of moving companies to a different state takeover regime. Even if it were the case that the first factor (subjecting the company to a different state takeover regime) has a sufficiently large negative effect on stock prices so that all the antitakeover-motivated reincorporations are accompanied by a negative abnormal return, this negative abnormal return would still be an upward biased estimate of the lower return caused by the first factor alone. And this upward bias in the documented returns for part of the reincorporation sample would, of course, increase average results for the sample as a whole.

\section{d. Different Reincorporation Categories}

Consistent with the significance of confounding events, two recent studies found that the abnormal returns experienced by reincorporating firms vary depending on the announced motivation for the firm's decision to reincorporate. Heron and Lewellen found that reincorporations motivated by a desire to erect takeover defenses were accompanied by statistically significant negative abnormal returns. ${ }^{59}$ In contrast, reincorporations motivated by a desire to limit directors' liability resulted in positive abnormal returns. ${ }^{60}$ Peterson's reincorporation event study also documented that abnormal returns differed depending on the announced motivation for reincorporation. ${ }^{61}$ If the motivation for the reincorporation was defensive in nature, the abnormal return was $-.16 \%$, while other reincorporations experienced a positive abnormal return of $.65 \%{ }^{62}$

Romano's 1985 study broke down reincorporations into three groups: reincorporations that seemed motivated by mergers and acquisition programs; reincorporations that seemed motivated by antitakeover considerations; and a miscellaneous group consisting of all the remaining reincorporations. She found that each of the three groups had a substantially different average abnormal return but that the variance of the three associated abnormal returns was not statistically significant. ${ }^{63}$

In recent papers, Sanjai Bhagat and Roberta Romano argue that, based on Romano's 1985 study, confounding events do not influence the returns reported in the event studies literature. ${ }^{64}$ Bhagat and Romano interpret the lack of statistically significant differences between the three groups as evidence that "significant positive returns upon reincorporation can be

59. Heron \& Lewellen, supra note 38, at 549-68.

60. Id. at 550,557 tbl. 5 .

61. See Peterson, supra note 39.

62. See generally Bhagat \& Romano, supra note 3, at 385 (discussing Peterson's study along with other event studies).

63. Romano, Law as a Product, supra note 2, at 272. Peterson's study, which also found different abnormal returns across subgroups of reincorporating firms, did not test the statistical significance of the returns' variance.

64. See, e.g., Bhagat \& Romano, supra note 3, at 387. 
attributed to investors' positive assessment of the change in legal regime, not a confounding of the impact of reincorporating firms' other future projects." ${ }^{\prime 65}$ But this inference, which the 1985 study did not make, is unwarranted.

To start, such an inference would overlook the different conclusions reached by more recent studies. Perhaps more importantly, Romano's 1985 testing was not designed to address the confounding events issue. The testing examined whether reincorporations with different motivations had different effects on stock market values. Tests for confounding events should focus on all the information that was publicly known at the time of the reincorporation, but the information on which Romano's 1985 study relied differed from this category of information in two significant ways. First, Rounano's analysis used for the classification information that was not publicly known at the time of the reincorporation, such as information about acquisitions in the year following the reincorporation and information disclosed to Romano privately in response to the questionnaire she circulated to firms many years after their reincorporation. Second, Romano's analysis did not include some public information that would be relevant for studying the confounding events question, such as how the earnings and other financial disclosures of reincorporating companies at the time of their reincorporation compared with those of nonreincorporating compamies. ${ }^{66}$

In sum, there are good reasons, grounded in the empirical evidence, to believe that reincorporations are accompanied by confounding events that can help explain the documented positive abnormal returns. What is lacking in the literature to date is a better understanding of what causes firms to incorporate at given times in particular jurisdictions. We will return to this issue in Part IV.

\section{II}

\section{Does a Marginal Superiority OF DELAWARE INCORPoRation IMPLy THAT STATE COMPETITION BENEFITS INVESTORS?}

Part I questioned whether the available empirical evidence demonstrates that Delaware's legal regime benefits investors more than that of other states. In this Part, we change directions and assume that incorporation in Delaware does add some value, even if it is difficult to measure. It

65. Id.; see also Romano, Genius, supra note 2, at 18.

66. It is also worth noting that the breakdown of reincorporating firms into groups in Romano's 1935 study involved substantial "noise" which made it difficult to get statistically significant results. Given that the breakdown into groups involved a great deal of noise (as the study itself readily admits), the 1985 study prudentially emphasizes that this noise "may very well be the source of the test's inability to find any significant difference among the groups." Romano, Law as a Product, supra note 2 , at 272 . The only conclusion that the 1985 study was prepared to make was that "[w]e cannot conclude definitely that the stock returns for the different types of reincorporations are significantly different." Id. 
is reasonable to assume that reincorporation often adds some value; otherwise, shareholders would tend not to vote to reincorporate. But what are the implications of such benefits for the merits of state competition?

Many scholars have assumed, without much discussion, that the presence of benefits to shareholders from Delaware incorporation would prove that state competition benefits investors. ${ }^{67}$ This assumption is not valid, however. The relative performance of Delaware in a state competition system and the overall performance of the state competition system are two separate issues. Findings of Delaware marginal superiority do not address the question of how well state competition is performing overall and, in particular, whether it performs better than would an alternative regime. And it is the performance of the state competition regime overall that is at the heart of the debate surrounding state competition for corporate charters.

\section{A. The Need to Evaluate States' Collective Performance}

It is worthwhile emphasizing that, in many respects, the various states' corporate regimes are not very different from each other when compared against the range of possible choices and the laws of other countries. This feature of U.S. corporate law has been well documented in William Carney's comprehensive study of state corporate law. ${ }^{68}$ The similarity is especially noteworthy in light of the existence of fifty-one separate corporate codes and the resulting opportunity for a wide variety of approaches to many corporate law issues. ${ }^{69}$

Given the fundamental similarity among state corporate law regimes, assessing the collective approach that the states have adopted in most areas of corporate regulation is as important in assessing the value of state competition as evaluating some of the real differences (such as in the area of takeover regulation) that do exist between states. This assessment of states' collective approach should focus on those areas where there is a substantial divergence between the interests of managers and shareholders. It is in these areas that states, including Delaware, are likely to collectively adopt a suboptimal position.

67. See supra notes $9-10$ and accompanying text.

68. William J. Carney, The Production of Corporate Law, 71 S. CAL. L. Rev. 715 (1998); see also John C. Coffee, Jr., The Future as History: The Prospects for Global Convergence of Corporate Governance and Its Implications, 93 Nw. U. L. REv. 641, 702 (1999) ("[T] he best documented finding in the empirical literature on the U.S. corporate chartering competition is that a high degree of uniformity has emerged in American corporate laws.").

69. For example, despite the large number of U.S. jurisdictions, none of them has offered, as the British City Code has done, a clear and categorical ban on the use of defensive tactics in the presence of a bona fide tender offer in the absence of shareholder approval. See 2 P.F.C. BEGG, CoRPorate Acquisitions and Mergers: A Practical Guide to the Legal, Financial, and Administrative IMPLICATIONS (Graham \& Trotman Limited, 1985). 


\section{B. A Skeptical Account of State Competition Is Consistent with Delaware Marginal Superiority}

The superiority of Delaware's legal regime, as purportedly documented by the studies we reviewed in Part I of this Article, is consistent with a pro-state competition position. But such a finding is equally consistent with a more skeptical theory of how state competition works and, therefore, is inconclusive in adjudicating the debate over state competition. Indeed, any account of state competition-whether critical or supportivethat takes into account the substantial uniformity among states im substantive arrangements, would likely start from the premise that Delaware's corporate regime is marginally better. If all states have essentially the same substantive rules, it is likely that Delaware's unique nonsubstantive advantages will outweigh any of the relatively small differences that exist among states. Delaware is the beneficiary of network externalities and a well developed legal infrastructure. ${ }^{70}$

For example, consider the following skeptical account of state competition. Just as shareholders presumably approve remcorporations when they increase firm value, a decision by managers not to reincorporate, which is not reviewable by shareholders under state law, is presumably in the interests of managers. With respect to certain corporate law subjects, there will often be a substantial divergence between the interests of managers and those of shareholders. In such circumstances, Delaware, as well as other states, will care a great deal about satisfying managers' preferences, as states will wish to prevent managers from pursuing reincorporation elsewhere. $^{71}$

As we have argued in earlier work, corporate rules that are significantly redistributive from shareholders to managers and rules that affect the discipline of the market are likely areas where states, as a result of the competition for corporate charters, will fail to maximize shareholder wealth. The failure to maximize shareholder wealth in these areas will be true not only of Delaware but of other states as well. As a result, it would be theoretically possible for there to be a competitive equilibrium if it were true both that: (1) states adopt corporate law regimes which tend to favor managerial imterests over shareholder interests where there is substantial divergence of interests; and (2) reincorporation to Delaware often provides some additional value, on the inargin, to shareholders if Delaware offers advantages not reflected in its substantive rules. This reasoning can

70. See generally Fisch, supra note 3.

71. See Bebchuk, supra note 2; Bebchuk \& Ferrell, Federalism and Corporate Law, supra note 3. 
be captured formally in a model where such an outcome is a competitive equilibrium. ${ }^{72}$

Even if it were empirically true (which we do not believe it is) that the superiority of Delaware for many shareholders lies in its having a better substantive regime, this should still be the beginning, not the end, of the analysis. Where states have ended up overall could still be questioned. One could, for example, imagine a takeover regime, such as the one embodied in the British City Code, ${ }^{73}$ that is far more hospitable to takeovers than that of Delaware or any other state. Or one might believe that it would be preferable to have a regime even more protective of target management than that currently provided by any state. A regime in which dead-hand and slow-hand poison pills ${ }^{74}$ were permitted and routinely used would be one such example.

\section{III}

\section{Does State Competition Work Well in the Area of Takeover REgulation?}

Despite the substantial similarity in state corporate law regimes, there is some significant variance among states in their regulation of takeovers. Although most states have adopted some antitakeover statutes, important differences remain between states' antitakeover stances. Supporters of state competition have sought to reconcile their position that competition works well with the view, which is supported by the evidence, that antitakeover statutes often do not serve shareholders. To this end, they have made empirical claims that state competition does not reward, and thus does not contribute to, the adoption of antitakeover protections. As this Part shows, however, these empirical claims are unconvincing.

\section{A. The View that States Restrict Takeovers Excessively}

State takeover law consists of two basic components. First, states impose rules on bidders wishing to acquire companies. These rules are usually contained in antitakeover statutes. Second, takeover law includes rules governing the use of defensive tactics by managers wishing to defeat an unwanted takeover bid. In Delaware, the law on defensive tactics consists almost entirely of judge-made law. In other states, statutory law plays a

72. See Oren BAR-Gill ET AL., supra note 7. This model does differ from the position adopted by William Cary in an important respect. Cary believed in a "race to the bottom" equilibrium in which Delaware was offering especially poor corporate rules. See Cary, supra note 1. In contrast, this model puts forward a race-to-the-bottom equilibrium in which Delaware is slightly better than other states with respect to serving shareholders' interests.

73. See Bebchuk \& Ferrell, A New Approach, supra note 3, at 129-30 (describing the British City Code regime).

74. These types of poison pills are more difficult for a board of directors to rescind than standard poison pills. 
more important role in the form of poison-pill-endorsement statutes and constituency statutes. ${ }^{75}$

While case law, such as Delaware's law on the use of defensive tactics, is extremely important, empirical studies of the effect of takeover law on shareholder wealth has focused on antitakeover statutes, including statutes addressing the use of defensive tactics. Because these statutes are proposed and adopted on specific dates, they allow for empirical estimation of their effects. The evidence from this research consistently shows that antitakeover statutes virtually never increase firm value and, in fact, often de-

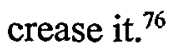

While a typical antitakeover statute has a negative, albeit modest, effect on shareholder value, there are three states that have gained notoriety for the extreme nature of their antitakeover statutes. Massachusetts, Ohio, and Pennsylvamia have adopted antitakeover statutes ${ }^{77}$ that either impede or substantially reduce the attractiveness of takeovers above and beyond that normally associated with state antitakeover statutes. All three antitakeover statutes have been heavily criticized and identified in empirical studies as causing a substantial reduction in firm value. ${ }^{78}$

Supporters of state competition are among those who tend to believe that states often restrict takeovers excessively. For instance, Ralph Winter, one of the early influential proponents of the pro-state competition position, has expressed his belief that a legal regime that facilitates takeovers increases firm value. ${ }^{79}$ Frank Easterbrook and Daniel Fischel have famously argued that managers should be "passive" in the face of a takeover and not engage in defensive tactics. ${ }^{80}$ Another leading pro-state

75. Poison-pill-endorsement statutes explicitly authorize the use of the "poison pill" defense against hostile takeovers, a defense that is often highly effective. Constituency statutes explicitly permit target management to take into account the interests of nonshareholder groups, such as employees, to justify fending off hostile takeovers.

76. See, e.g., Jonathan M. Karpoff \& Paul H. Malatesta, The Wealth Effects of SecondGeneration State Takeover Legislation, 25 J. FIN. ECON. 291 (1989) (noting that forty secondgeneration statutes adopted in twenty-six states had, on average, a -.294\% impact on stock prices on the date that the earliest known newspaper article concerning the proposed legislation appeared). For a survey of the many event studics on state antitakeover statutes, see GRANT GARTMAN, supra note 12 , STATE ANTITAKEOVER LAWs (on file with authors).

77. See supra notes 12-14.

78. See Jonathan M. Karpoff \& Paul H. Malatesta, Pennsylvania Law: State Antitakeover Laws and Stock Prices, 46 FIN. ANAlyst J. 8 (1990) (examining Pennsylvania's antitakeover statute); L. Mick Swartz, The 1990 Pennsylvania Antitakeover Law: Should Firms Opt Out of Antitakeover Legislation, 11 J. Acct., Auditing, \& Fin. 223 (1996) (examining Pennsylvania's antitakeover statute); Samuel J. Szewcyk \& George P. Tsetsekos, State Intervention in the Market for Corporate Control: The Case of Pennsylvania Senate Bill 1320, 31 J. FIN. Econ. 3 (1992) (examining Pennsylvania's antitakeover statute); Robert Daines, Do Staggered Boards Affect Firm Value? Massachusetts and the Market for Corporate Control (2001) (unpublished working paper, on file with authors) (examining Massachusetts's antitakeover statute).

79. Winter, supra note 2, at 289.

80. See generally Frank H. Easterbrook \& Daniel R. Fischel, The Proper Role of a Target's Management in Responding to a Tender Offer, 94 HARV. L. REv. 1161 (1981). 
competition theorist, Roberta Romano, has forthrightly acknowledged the "dismal track records of most states in takeover regulation."

How do supporters of state competition square this circle? The stock response has been to emphasize the fact that Delaware, the leading corporate law jurisdiction, has a less restrictive antitakeover statute than that of many other states. They reason that if the most successful state has among the mildest of antitakeover statutes, then it follows that state competition does not encourage states to impose excessive antitakeover protections. Specifically, supporters of state competition have made the following four claims: (1) Delaware corporations have a higher incidence of bids and a higher acquisition rate, indicating that Delaware's takeover law is more hospitable to takeovers; (2) Direct observation of the terms of states' antitakeover laws also reveals that Delaware's takeover regime is relatively moderate; (3) The market for incorporations has penalized those states that have enacted extreme antitakeover statutes, such as Massachusetts, Ohio, and Pennsylvania; and (4) The adoption of state antitakeover statutes is largely outside the normal parameters of state competition for incorporations. We will examine each of these four claims in turn.

\section{B. Claims that Delaware Corporations Are Acquired More Often}

Robert Daines's Tobin's Q study, discussed in Part I, identified Delaware's takeover regime as one of the factors accounting for a higher Tobin's Q among Delaware firms. ${ }^{82} \mathrm{He}$ found that Delaware firms are more likely to receive bids and are more likely to be acquired than nonDelaware firms. ${ }^{83}$ Daines attributed the different bid and acquisition rates of Delaware firms to Delaware's provision of fewer impediments to hostile bids. $^{84}$

This attribution of the different bid and acquisition rates of Delaware firms to Delaware's takeover law is unwarranted for several reasons. First, although cleanly separating friendly and hostile acquisitions is tricky, ${ }^{85}$ Daines fails to distinguish between friendly and hostile acquisitions. Because the majority of all acquisitions are friendly, the difference in acquisition incidence might be due in large part to differences in the incidence of friendly acquisitions of Delaware and non-Delaware firms. Even if one were to take the view that Delaware is mildly more hospitable to hostile

81. Roberta Romano, Competition for Corporate Charters and the Lesson of Takeover Statutes, 61 Fordham L. Rev. 843, 860 (1993).

82. Daines, supra note 3, at 542-49. On a related note, Peter Dodd and Richard Leftwich attribute the high rate of reincorporation to Delaware in the late 1960 s to Delaware's relatively permissive stance on mergers and tender offers. See Dodd \& Leftwich, supra note 37, at 268.

83. Daines, supra note 3 , at 547.

84. Id. at $542-49$.

85. See G. William Schwert, Hostility in Takeovers: In the Eyes of the Beholder?, 55 J. FIN. 2599 (2000). 
takeovers than other states, it would be hard to attribute a substantial difference in the incidence of friendly acquisitions to this mild difference in the treatment of hostile acquisitions. ${ }^{86}$

Rather than attributing the different acquisition (and bid) rates to differences in the treatment of hostile bids, the more plausible explanation for the differences between Delaware and non-Delaware firms is once again self-selection. Firms choosing to incorporate in Delaware are different in some way, and the differences between them and non-Delaware firms could be responsible for the different bid and acquisition rates. This theory is more plausible because the differences between Delaware takeover law and that of most other states are relatively minor, as we will explain in the next Section, and are therefore unlikely to account for the observed variation in the overall incidence of friendly and hostile acquisitions. Interestingly, a recent empirical study found that whether a target firm is a Delaware firm or not has no effect on the outcome of a hostile bid. ${ }^{87}$ In sum, Daines's findings do not provide a firm basis for concluding that Delaware is more hospitable to takeovers than other states.

\section{Claims that Delaware's Takeover Law Is Relatively Moderate}

1t is far from clear that Delaware offers less antitakeover protection than most other states. While it is true that some states have more antitakeover statutes or antitakeover statutes of a more extreme nature, others, such as California, have no such statutes.

More importantly, an assessment of Delaware's relative position cannot be based merely on a comparison of antitakeover statutes because case law plays a central role in Delaware's takeover regulation. Delaware has a well developed body of case law, which makes the absence of some types of antitakeover statutes practically irrelevant. Delaware's judges have played an active role in developing legal doctrines that permit the use of defensive tactics in general and the potent poison pill defense in particular. ${ }^{88}$ Because of the large body of Delaware judge-made law upholding the indefinite use of poison pills, ${ }^{89}$ there is no need for an antitakeover statute explicitly authorizing the use of poison pills (a poison-pill-endorsement statute) or for an antitakeover constituency statute that provides managers with discretion to defend against bids.

86. Guhan Subramanian found no differences between Delaware and non-Delaware firms in terms of the incidence of hostile bids. Subramanian, supra note 15. Thus, according to this evidence, the difference in acquisition rates is largely due to the incidence of friendly acquisitions.

87. See Lucian A. Bebchuk et al., The Powerful Antitakeover of Staggered Boards: Theory, Evidence, and Policy, 54 STAN. L. Rev. 887 (2002).

88. See Bebchuk \& Ferrell, A New Approach, supra note 3, at 117-28.

89. Id. 
Furthermore, Delaware's case law on the use of poison pills has rendered the absence of a control-share-acquisition antitakeover statute ${ }^{90}$ and a fair-price antitakeover statute ${ }^{91}$ practically irrelevant; as long as a poison pill is in place, any additional antitakeover defense is superfluous since the pill completely blocks a bidder from proceeding. Were a bidder to overcome the poison pill defense by taking control of the target corporation's board in a proxy contest (and having the poison pill redeemed by the board), a control-share-acquisition antitakeover statute and a fair-price antitakeover statute, which are usually only applicable to bids that the board does not approve, would still be irrelevant.

In contrast, the adoption of additional antitakeover statutes might be more significant events for states with less developed case law. Poison-pillendorsement statutes and constituency statutes in such states might provide managers with the confidence, notwithstanding the limited case law in the state, that indefinite use of a poison pill defense will be tolerated. Furthermore, the adoption of additional antitakeover statutes may also convey the message that the state is committed to providing substantial protection to managers who are facing unwanted takeovers. Delaware has already sent this message loud and clear through its case law. Thus, it is far from evident that Delaware's antitakeover law is more moderate; any comparison between Delaware's takeover regime and those of other states must take into account the central role in takeover regulation played by Delaware's extensive case law.

Although it is difficult to compare Delaware's takeover regime directly to that of other states, much can be learned about the merits of state competition from a more systematic comparison of how states other than Delaware fare in the incorporation market when they adopt various antitakeover statutes. Given that these states vary widely in their antitakeover statutes and how they fare in the incorporation market, a cross-comparison within the group of non-Delaware companies would be helpful in obtaining a better understanding on how the incorporation market reacts to different levels of antitakeover protection. Part IV discusses this approach.

\section{Claims that Outlier States Have Been Penalized}

Supporters of state competition often point to the extreine antitakeover statutes of Massachusetts, Ohio and Pennsylvania as examples of Delaware's virtue. Consistent with this view, pro-state competition schol$\operatorname{ars}^{92}$ have suggested that these three states have been penalized rather than

90. Control-share-acquisition statutes typically require an acquirer to obtain approval of the shareholders before it can exercise the voting rights of the control share.

91. Fair-price statutes regulate the price at which acquirers can purchase outstanding shares.

92. See EAsterbrooK \& Fischel, supra 2; Romano, Genius, supra note 2; Romano, Law as a Product, supra note 2. 
rewarded by the incorporation market as a result of their actions. Moreover, these scholars have directed some of their empirical work towards documenting the adverse effects that these extreme antitakeover statutes have had on shareholders.

For example, Robert Daines has found that Massachusetts companies have lower Tobin's Qs than those of Delaware firms. ${ }^{93}$ In another study, Daines found that the adoption of Massachusetts's antitakeover statute was accompanied by a significant reduction in the share value of Massachusetts companies. ${ }^{94}$ This second study is consistent with earlier studies that found strong negative stock reactions to the adoption of the antitakeover statutes of all three states. However, this work simply shows that the antitakeover statutes of these states harm shareholders, a point with which we readily agree. This harm to shareholders in no way establishes that these states have, in fact, been penalized by the incorporation market as a result of their bad behavior.

Roberta Roinano has pointed out that many Pennsylvania companies have opted out of Pennsylvania's extreme antitakeover statute. ${ }^{95}$ She argues that this indicates that state conipetition has worked well. However, such an inference should not be drawn. Because the opt-out procedure under the Pennsylvania antitakeover statute was simple, the managers of Pennsylvania companies that chose to opt out were not harmed by the passage of the statute. In contrast, those managers of companies that did not opt out obtained substantial antitakeover protections that they would not have enjoyed otherwise. The substantial incidence of opting out thus does not imply that the passage of the Pennsylvania antitakeover statute did not serve managerial interests at a substantial fraction of Pennsylvania companies at shareholders' expense. More to the point, it does not iniply that passage of the statute harmed Pennsylvania in the market for corporate charters.

The evidence provided by the supporters of state competition therefore fails to demonstrate that the outlier states have actually been disadvantaged in the incorporation market, as they should have been if state competition does, as its supporters assert, penalize the adoption of shareholder-welfare-reducing corporate rules. Surprisingly, supporters of state competition have made no effort to directly test their prediction that the actions of the outlier states would actually hurt them in the incorporation market. As we shall discuss in Part IV, this predicted effect does not im fact exist.

93. Daines, supra note 3 , at 546.

94. See Daines, supra note 78 (examining Massachusetts' antitakeover statute).

95. See RoMano, Genius, supra note 2, at 68-70. 


\section{E. Claims that Antitakeover Statutes Are Outside the Parameters of State Competition}

In an effort to reconcile their views on state competition with the evidence on antitakeover statutes, state competition proponents have also argued that many antitakeover statutes were passed to prevent particular, politically influential local companies from being acquired. Therefore, proponents argue, these statutes represent an aberration outside of the normal parameters of state competition..$^{96}$ On this view, even though the adoption of such statutes does not serve and indeed hurts the goal of attracting incorporations, states have adopted them because of the political power of some in-state corporate targets. ${ }^{97}$

As Ralph Winter puts it: "The problem is not that states compete for charters but that too often they do not." $" 98$ The desire to increase the number of incorporations does not encourage states to adopt antitakeover statutes; to the contrary, it moderates their tendency, due to lobbying by firms, to do so. This argument predicts that states that adopt antitakeover statutes to protect particular companies, disregarding the incorporation market, will attract fewer incorporations as a result.

Supporters of state competition have made no attempt, however, to test this prediction by examining how the adoption of antitakeover statutes has actually affected states' success in the incorporation market. As we shall discuss in Part IV, the evidence does not confirm this prediction but rather indicates that adopting antitakeover statutes makes states more, not less, successful in the incorporation market.

\section{IV}

\section{Recent Evidence on the Determinants of InCorporation Decisions}

\section{A. A New Approach}

A natural way to determine how state competition actually works, and whether or not it benefits shareholders' interests, is to focus directly on how the choices states make with regard to corporate legal regimes affect their competitive position in the market for corporate charters. According to the race-to-the-top position, states that adopt legal regimes that diminish shareholder wealth should suffer by attracting fewer incorporations. Conversely, states that adopt legal regimes that enhance shareholder wealth should be rewarded with increased numbers of incorporations. These are testable propositions.

96. See, e.g., Winter, supra note 2, at 270.

97. See Roberta Romano, The Political Economy of Takeover Statutes, 73 VA. L. REv. 111 (1987).

98. Ralph K. Winter, Foreword, in Romano, Genius, supra note 2, at xi. 
Unfortunately, prior empirical work has not pursued this approach. Rather, the question it has asked is: Given incorporation decisions, does Delaware incorporation increase firm value? ${ }^{99}$ As Part I has emphasized, this analysis is often equivalent to assuming that incorporation decisions are random events, allowing researchers to treat an incorporation decision as a given. But the fundamental premise of the state competition debate, whichever side one takes, is that incorporation decisions are not random but deliberate.

Another shortcoming of most existing expirical work is that it typically begins its analysis by dividing the incorporation market between Delaware and non-Delaware firms. It then investigates whether incorporating in (or reincorporating to) Delaware benefits investors. This approach effectively lumps together all the non-Delaware states into one undifferentiated mass and thus overlooks important variations that exist among the non-Delaware states.

The variations among the non-Delaware states are significant in certain respects. In particular, states vary widely in how successful they are in retaining companies already headquartered in them ("in-state coinpanies") and in attracting corporations headquartered elsewhere ("out-of-state companies"). Furthermore, although states are overall rather similar in their corporate laws, there is still significant variance among states in some areas of corporate law, such as takeover law. Thus, the variation ainong states both in terms of their laws and in terms of their success in the incorporation market provides a natural laboratory for exainining which corporate rules make states more or less attractive.

There is yet another advantage of our approach that is worth highlighting. Delaware is a special case because of the important institutional advantages it offers shareholders. Thus, in comparisons between Delaware and non-Delaware corporations, it is difficult to disentangle the effects of these institutional advantages from the effects of different substantive corporate rules. By focusmg on the large set of non-Delaware states, it is possible to make comparisons among states, none of which has the special "Delaware advantages." Removing this variable makes it easier to identify the effects that variations in legal rules have on the distribution of incorporations.

Below we illustrate the value of this approach by presenting some summary statistics and simple cross-state comparisons. A separate study by two of us (the Incorporation Study) has carried out a full empirical analysis of the determinants of domicile decisions. ${ }^{100} \mathrm{We}$ will focus here on the findings of this study concerning how takeover rules affect states' ability to

99. See, e.g., Hyman, supra note 37.

100. See Bebchuck \& Cohen, supra note 15. 
retain in-state companies as well as their ability to attract out-of-state companies. ${ }^{101}$

The approach that we propose can also be applied to identify how aspects of state corporate law, other than state takeover law, affect companies' domicile decisions. For example, the Incorporation Study analyzes how a state's adoption of the Revised Model Business Corporation Act ("RMBCA") affects its success. ${ }^{102}$ We focus here on takeover rules, however, because of the importance of these rules in the debate over the merits of state competition. We start by describing how incorporations are distributed among the states. We then exanine the distribution of various types of antitakeover statutes. Finally, we analyze these patterns to determine whether or not antitakeover statutes actually help states retain in-state companies and attract out-of-state companies.

\section{B. The Pattern of Incorporations}

How does each state fare in terms of retaining its in-state companies and attracting out-of-state companies? Surprisingly, most of the empirical work on state conipetition has not documented these basic patterns of incorporation. Indeed, it has not even documented how the $50 \%$ of total incorporations not captured by Delaware are currently distributed aniong different states.

The patterns we describe account for all the incorporations of nonfinancial publicly traded companies for which there was data in the Compustat database at the end of 1999 and which have both their headquarters and their incorporations in the United States. ${ }^{103}$ There were 6530 such companies. Table 1 displays how the headquarters of these companies are distributed among states. By "states" we mean throughout the fifty-one jurisdictions consisting of the fifty states and the District of Columbia.

101. Guhan Subramanian also studies empirically the effects of antitakeover statutes on the ability of states to retain their in-state companies. See Subramanian, supra note 15. As will be discussed below, his conclusions are consistent with those of Bebchuk and Cohen's Incorporation Study, supra note 15 , with respect to standard antitakeover statutes but not with respect to extreme statutes. He does not study the effect of states' antitakeover statutes on their success in attracting out-of-state companies.

102. It was found that adopting the RMBCA did not help states retain their in-state companies and it made states less attractive to out-of-state companies. See Bebchuck \& Cohen, supra note 15, at 13.

103. In focusing on nonfinancial firms we follow the approach of Robert Daines's study, supra note 3. When financial companies are included, the results are qualitatively the same. 
TABLE 1

The Distribution of Firm Locations Among States

\begin{tabular}{|l|c|c|}
\hline State & $\begin{array}{c}\text { Number of firms } \\
\text { located in state }\end{array}$ & Percentage \\
\hline $\mathrm{CA}$ & 1,254 & $19.20 \%$ \\
\hline $\mathrm{TX}$ & 586 & $8.97 \%$ \\
\hline $\mathrm{NY}$ & 576 & $8.82 \%$ \\
\hline $\mathrm{MA}$ & 360 & $5.51 \%$ \\
\hline $\mathrm{FL}$ & 328 & $5.02 \%$ \\
\hline $\mathrm{NJ}$ & 311 & $4.76 \%$ \\
\hline $\mathrm{PA}$ & 248 & $3.80 \%$ \\
\hline $\mathrm{I}$ & 241 & $3.69 \%$ \\
\hline $\mathrm{MN}$ & 212 & $3.25 \%$ \\
\hline $\mathrm{CO}$ & 201 & $3.08 \%$ \\
\hline $\mathrm{OH}$ & 192 & $2.94 \%$ \\
\hline $\mathrm{GA}$ & 178 & $2.73 \%$ \\
\hline $\mathrm{VA}$ & 154 & $2.36 \%$ \\
\hline $\mathrm{CT}$ & 147 & $2.25 \%$ \\
\hline $\mathrm{WA}$ & 131 & $2.01 \%$ \\
\hline $\mathrm{MI}$ & 104 & $1.59 \%$ \\
\hline $\mathrm{MD}$ & 101 & $1.55 \%$ \\
\hline $\mathrm{MO}$ & 101 & $1.55 \%$ \\
\hline $\mathrm{NC}$ & 98 & $1.50 \%$ \\
\hline $\mathrm{AZ}$ & 91 & $1.39 \%$ \\
\hline
\end{tabular}


Table 2 displays the distribution of incorporations among states. A comparison of Tables 1 and 2 reveals the considerable differences between the distributions of headquarters and incorporations.

TABLE 2

THE DisTribution OF INCORPORATIONS AMONG STATES

\begin{tabular}{|l|c|c|}
\hline State & $\begin{array}{c}\text { Number of firms } \\
\text { incorporated in state }\end{array}$ & Percentage \\
\hline DE & 3,771 & $57.75 \%$ \\
\hline CA & 283 & $4.33 \%$ \\
\hline NY & 226 & $3.46 \%$ \\
\hline NV & 217 & $3.32 \%$ \\
\hline MN & 178 & $2.73 \%$ \\
\hline FL & 165 & $2.53 \%$ \\
\hline TX & 147 & $2.25 \%$ \\
\hline CO & 132 & $2.02 \%$ \\
\hline PA & 124 & $1.90 \%$ \\
\hline MA & 118 & $1.81 \%$ \\
\hline OH & 112 & $1.72 \%$ \\
\hline NJ & 111 & $1.70 \%$ \\
\hline GA & 83 & $1.27 \%$ \\
\hline WA & 79 & $1.21 \%$ \\
\hline VA & 74 & $1.13 \%$ \\
\hline M1 & 60 & $0.92 \%$ \\
\hline WI & 57 & $0.87 \%$ \\
\hline MD & 54 & $0.83 \%$ \\
\hline OR & 54 & $0.83 \%$ \\
\hline UT & 52 & $0.80 \%$ \\
\hline IN & 50 & $0.77 \%$ \\
\hline NC & 46 & $0.70 \%$ \\
\hline TN & 39 & $0.60 \%$ \\
\hline MO & 36 & $0.55 \%$ \\
\hline IL & 32 & $0.49 \%$ \\
\hline Other & 230 & $3.52 \%$ \\
\hline Total & & $100 \%$ \\
\hline & 530 & \\
\hline
\end{tabular}

Table 3 displays how each state fares in the market for incorporations. The Table displays the following for each state: (1) how many of its in-state companies it retains, both in absolute numbers and as a percentage of all in-state companies; and (2) how many out-of-state companies it attracts, again in absolute numbers and as a percentage of all out-of-state incorporations. 
TABLE 3

Migration and Emigration in the "Market for Corporate Law"

\begin{tabular}{|l|c|c|c|c|c|}
\hline & $\begin{array}{c}\text { Number } \\
\text { of firms } \\
\text { located } \\
\text { in state }\end{array}$ & $\begin{array}{c}\text { Number of firms } \\
\text { located and } \\
\text { incorporated } \\
\text { in state }\end{array}$ & $\begin{array}{c}\text { As percentage of } \\
\text { all firms located } \\
\text { in this state }\end{array}$ & $\begin{array}{c}\text { Number of firms } \\
\text { located elsewhere } \\
\text { but incorporated } \\
\text { in state }\end{array}$ & $\begin{array}{c}\text { As percentage of } \\
\text { all out-of state } \\
\text { incorporations }\end{array}$ \\
\hline $\mathrm{AK}$ & 2 & 1 & $50.00 \%$ & 2 & $0.03 \%$ \\
\hline $\mathrm{AL}$ & 29 & 3 & $10.34 \%$ & 2 & $0.03 \%$ \\
\hline $\mathrm{AR}$ & 20 & 3 & $15.00 \%$ & 0 & $0.00 \%$ \\
\hline $\mathrm{AZ}$ & $9 \mathrm{l}$ & 21 & $23.08 \%$ & 0 & $0.00 \%$ \\
\hline $\mathrm{CA}$ & 1,254 & 273 & $21.77 \%$ & 10 & $0.19 \%$ \\
\hline $\mathrm{CO}$ & 201 & 74 & $36.82 \%$ & 58 & $0.92 \%$ \\
\hline $\mathrm{CT}$ & 147 & 17 & $11.56 \%$ & 3 & $0.05 \%$ \\
\hline $\mathrm{DC}$ & 25 & 2 & $8.00 \%$ & 0 & $0.00 \%$ \\
\hline $\mathrm{DE}$ & 27 & 27 & $100.00 \%$ & 3,744 & $57.57 \%$ \\
\hline $\mathrm{FL}$ & 328 & 137 & $41.77 \%$ & 28 & $0.45 \%$ \\
\hline $\mathrm{GA}$ & 178 & 71 & $39.89 \%$ & 12 & $0.19 \%$ \\
\hline $\mathrm{HI}$ & 13 & 6 & $46.15 \%$ & 2 & $0.03 \%$ \\
\hline $\mathrm{IA}$ & 25 & 10 & $40.00 \%$ & 4 & $0.06 \%$ \\
\hline $\mathrm{ID}$ & 15 & 2 & $13.33 \%$ & 1 & $0.02 \%$ \\
\hline $\mathrm{IL}$ & 241 & 27 & $11.20 \%$ & 5 & $0.08 \%$ \\
\hline $\mathrm{IN}$ & 56 & 39 & $69.64 \%$ & 11 & $0.17 \%$ \\
\hline $\mathrm{KS}$ & 35 & 11 & $31.43 \%$ & 8 & $0.12 \%$ \\
\hline $\mathrm{KY}$ & 29 & 7 & $24.14 \%$ & 2 & $0.03 \%$ \\
\hline $\mathrm{LA}$ & 45 & 18 & $40.00 \%$ & 4 & $0.06 \%$ \\
\hline $\mathrm{MA}$ & 360 & 108 & $30.00 \%$ & 10 & $0.16 \%$ \\
\hline $\mathrm{MD}$ & 101 & 25 & $24.75 \%$ & 29 & $0.45 \%$ \\
\hline $\mathrm{ME}$ & 10 & 4 & $40.00 \%$ & 0 & $0.00 \%$ \\
\hline $\mathrm{MI}$ & 104 & 58 & $55.77 \%$ & 2 & $0.03 \%$ \\
\hline $\mathrm{MN}$ & 212 & 158 & $74.53 \%$ & 20 & $0.32 \%$ \\
\hline $\mathrm{MO}$ & 101 & 26 & $25.74 \%$ & 10 & $0.16 \%$ \\
\hline $\mathrm{MS}$ & 14 & 4 & $28.57 \%$ & 8 & $0.12 \%$ \\
\hline $\mathrm{MT}$ & 6 & 6 & $100.00 \%$ & 0 & $0.00 \%$ \\
\hline $\mathrm{NC}$ & 98 & 38 & $38.78 \%$ & 0 & $0.00 \%$ \\
\hline $\mathrm{ND}$ & 4 & 0 & $0.00 \%$ & 0 & $0.00 \%$ \\
\hline $\mathrm{NE}$ & 18 & 4 & $22.22 \%$ & 3 & $0.05 \%$ \\
\hline $\mathrm{NH}$ & 28 & 3 & $10.71 \%$ & 0 & $0.00 \%$ \\
\hline $\mathrm{NJ}$ & 311 & 80 & $25.72 \%$ & 31 & $0.50 \%$ \\
\hline $\mathrm{NM}$ & 9 & 4 & $44.44 \%$ & 3 & $0.05 \%$ \\
\hline $\mathrm{NV}$ & 63 & 45 & $71.43 \%$ & 172 & $2.66 \%$ \\
\hline & & & & & \\
\hline
\end{tabular}


TABLE 3 (cont.)

\begin{tabular}{|l|c|c|c|c|c|}
\hline State & $\begin{array}{c}\text { Number } \\
\text { of firms } \\
\text { located } \\
\text { in state }\end{array}$ & $\begin{array}{c}\text { Number of firms } \\
\text { located and } \\
\text { incorporated } \\
\text { in state }\end{array}$ & $\begin{array}{c}\text { As percentage of } \\
\text { all firms located } \\
\text { in this state }\end{array}$ & $\begin{array}{c}\text { Number of firms } \\
\text { located elsewhere } \\
\text { but incorporated } \\
\text { in state }\end{array}$ & $\begin{array}{c}\text { As percentage of } \\
\text { all out-of state } \\
\text { incorporations }\end{array}$ \\
\hline NY & 576 & 141 & $24.48 \%$ & 85 & $1.43 \%$ \\
\hline OH & 192 & 105 & $54.69 \%$ & 7 & $0.11 \%$ \\
\hline OK & 61 & 22 & $36.07 \%$ & 5 & $0.08 \%$ \\
\hline OR & 70 & 50 & $71.43 \%$ & 4 & $0.06 \%$ \\
\hline PA & 248 & 98 & $39.52 \%$ & 26 & $0.41 \%$ \\
\hline RI & 24 & 6 & $25.00 \%$ & 1 & $0.02 \%$ \\
\hline SC & 30 & 9 & $30.00 \%$ & 1 & $0.02 \%$ \\
\hline SD & 7 & 4 & $57.14 \%$ & 0 & $0.00 \%$ \\
\hline TN & 81 & 33 & $40.74 \%$ & 6 & $0.09 \%$ \\
\hline TX & 586 & 139 & $23.72 \%$ & 8 & $0.13 \%$ \\
\hline UT & 70 & 32 & $45.71 \%$ & 20 & $0.31 \%$ \\
\hline VA & 154 & 56 & $36.36 \%$ & 18 & $0.28 \%$ \\
\hline VT & 11 & 4 & $36.36 \%$ & 0 & $0.00 \%$ \\
\hline WA & 131 & 68 & $51.91 \%$ & 11 & $0.17 \%$ \\
\hline W1 & 72 & 52 & $72.22 \%$ & 5 & $0.08 \%$ \\
\hline WV & 8 & 3 & $37.50 \%$ & 0 & $0.00 \%$ \\
\hline WY & 9 & 3 & $33.33 \%$ & 12 & $0.18 \%$ \\
\hline Total & 6530 & 2137 & & 4393 & \\
\hline Average & & & $38.10 \%$ & & $1.33 \%$ \\
\hline
\end{tabular}

Table 3 indicates that the large majority of states are net "exporters" of companies. The Tables also indicate that there is a great deal of variance among non-Delaware states in terms of how they fare, both in retaining instate companies and in attracting out-of-state companies. For example, whereas California retains only $21.77 \%$ of its in-state companies, Ohio and Washington retain more than 50\%, and Minnesota and Indiana retain approximately $70 \%$. As for out-of-state incorporations, while thirty-three states attract less than ten out-of-state incorporations each, there are four states with more than fifty each. The question on which we shall focus next is the extent to which this relative performance depends on the antitakeover statutes adopted by the various states.

\section{The Landscape of State Antitakeover Statutes}

Table 4, which is taken from Grant Gartman's comprehensive survey of state antitakeover statutes, ${ }^{104}$ indicates which antitakeover statutes each 
state has. Most states have at least one antitakeover statute. Pennsylvania, Ohio and Massachusetts also have nnique antitakeover statutes that will be discussed separately. The vast majority of these statutes were adopted during the period from 1985 to 1991.

TABLE 4

Standard ANTitakeover Statutes

\begin{tabular}{|l|c|c|c|c|c|c|}
\hline State & $\begin{array}{c}\text { Number of } \\
\text { Statutes }\end{array}$ & $\begin{array}{c}\text { Control } \\
\text { Share }\end{array}$ & Fair Price & $\begin{array}{c}\text { No } \\
\text { Freezeouts } \\
\text { prohibited) }\end{array}$ & $\begin{array}{c}\text { Poison Pill } \\
\text { Endorsement }\end{array}$ & Constituencies \\
\hline Alaska & 0 & 0 & 0 & 0 & 0 & 0 \\
\hline Alabama & 0 & 0 & 0 & 0 & 0 & 0 \\
\hline Arkansas & 0 & 0 & 0 & 0 & 0 & 0 \\
\hline Arizona & 4 & 1 & 1 & 3 & 0 & 1 \\
\hline California & 0 & 0 & 0 & 0 & 0 & 0 \\
\hline Colorado & 1 & 0 & 0 & 0 & 1 & 0 \\
\hline Connecticut & 3 & 0 & 1 & 5 & 0 & 1 \\
\hline DC & 0 & 0 & 0 & 0 & 0 & 0 \\
\hline Delaware & 1 & 0 & 0 & 3 & 0 & 0 \\
\hline Florida & 4 & 1 & 1 & 0 & 1 & 1 \\
\hline Georgia & 4 & 0 & 1 & 5 & 1 & 1 \\
\hline Hawaii & 3 & 1 & 0 & 0 & 1 & 1 \\
\hline Iowa & 3 & 0 & 0 & 3 & 1 & 1 \\
\hline Idaho & 5 & 1 & 1 & 3 & 1 & 1 \\
\hline llinois & 4 & 0 & 1 & 3 & 1 & 1 \\
\hline Indiana & 5 & 1 & 1 & 5 & 1 & 1 \\
\hline Kansas & 2 & 1 & 0 & 3 & 0 & 0 \\
\hline Kentucky & 4 & 0 & 1 & 5 & 1 & 1 \\
\hline Louisiana & 3 & 1 & 1 & 0 & 0 & 1 \\
\hline Massachusetts & 4 & 1 & 0 & 5 & 1 & 1 \\
\hline Maryland & 5 & 1 & 1 & 5 & 1 & 1 \\
\hline Maine & 1 & 0 & 0 & 0 & 0 & 1 \\
\hline Michigan & 3 & 1 & 1 & 5 & 0 & 0 \\
\hline Minnesota & 4 & 1 & 1 & 4 & 0 & 1 \\
\hline Missouri & 4 & 1 & 1 & 5 & 0 & 1 \\
\hline Mississippi & 3 & 1 & 1 & 0 & 0 & 1 \\
\hline Montana & 0 & 0 & 0 & 0 & 0 & 0 \\
\hline North Carolina & 3 & 1 & 1 & 0 & 1 & 0 \\
\hline North Dakota & 1 & 0 & 0 & 0 & 0 & 1 \\
\hline Nebraska & 2 & 1 & 0 & 5 & 0 & 0 \\
\hline New Hampshire & 0 & 0 & 0 & 0 & 0 & 0 \\
\hline New Jersey & 4 & 0 & 1 & 5 & 1 & 1 \\
\hline & & & & & & \\
\hline
\end{tabular}


TABLE 4 (cont.)

\begin{tabular}{|l|c|c|c|c|c|c|}
\hline State & $\begin{array}{c}\text { Number of } \\
\text { Statutes }\end{array}$ & $\begin{array}{c}\text { Control } \\
\text { Share }\end{array}$ & Fair Price & $\begin{array}{c}\text { No } \\
\text { Freezeouts } \\
\text { (years } \\
\text { prohibited }\end{array}$ & $\begin{array}{c}\text { Poison Pill } \\
\text { Endorsement }\end{array}$ & Constituencies \\
\hline New Mexico & 1 & 0 & 0 & 0 & 0 & 1 \\
\hline Nevada & 5 & 1 & 1 & 3 & 1 & 1 \\
\hline New York & 4 & 0 & 1 & 5 & 1 & 1 \\
\hline Ohio & 5 & 1 & 1 & 3 & 1 & 1 \\
\hline Oklahoma & 2 & 1 & 0 & 3 & 0 & 0 \\
\hline Oregon & 4 & 1 & 0 & 3 & 1 & 1 \\
\hline Pennsylvania & 5 & 1 & 1 & 5 & 1 & 1 \\
\hline Rhode Island & 4 & 0 & 1 & 5 & 1 & 1 \\
\hline South Carolina & 3 & 1 & 1 & 2 & 0 & 0 \\
\hline South Dakota & 5 & 1 & 1 & 4 & 1 & 1 \\
\hline Tennessee & 5 & 1 & 1 & 5 & 1 & 1 \\
\hline Texas & 1 & 0 & 0 & 3 & 0 & 0 \\
\hline Utah & 2 & 1 & 0 & 0 & 1 & 0 \\
\hline Virginia & 4 & 1 & 1 & 3 & 1 & 0 \\
\hline Vermont & 1 & 0 & 0 & 0 & 0 & 1 \\
\hline Washington & 3 & 0 & 1 & 5 & 1 & 0 \\
\hline Wisconsin & 5 & 1 & 1 & 3 & 1 & 1 \\
\hline West Virginia & 0 & 0 & 0 & 0 & 0 & 0 \\
\hline Wyoming & 3 & 1 & 0 & 3 & 0 & 1 \\
\hline Average/total & 2.7 & 27 & 27 & 32 & 25 & 31 \\
\hline
\end{tabular}

The standard antitakeover statutes are control-share-acquisition statutes, fair-price statutes, three-year no-freezeout business combination statutes, five-year no-freezeout business combination statutes, poison-pillendorsement statutes, and constituency statutes. Control-share-acquisition statutes typically require a would-be acquirer to win approval from a majority of outstanding disinterested shares before it can acquire control. Fairprice statutes attempt to ensure that an acquirer does not pay a premium for control and then buy the remaining shares at a lower price. No-freezeout business combination statutes prohibit acquirers, under certain conditions, from merging with the acquired company for a certain number of years, typically either three or five years. Poison-pill-endorsement statutes explicitly authorize the use of the poison pill defense by target management. Finally, constituency statutes authorize the use of defensive tactics, such as the poison pill defense, by target management in the name of nonshareholder constituencies, such as employees.

The antitakeover statutes adopted by states might have been important not only in what they actually did, but also arguably in the antitakeover 
message they sent. For instance, adopting the full arsenal of standard antitakeover statutes sends a clear antitakeover message to state courts and to potential and existing incorporators. Therefore, in assessing the overall level of protection against takeovers it is of interest to look at a state's total number of standard antitakeover statutes. To study cross-state differences in shareholder protection, the Incorporation Study uses an antitakeover index that attaches to each state a score from zero to five, which corresponds to the number of antitakeover statutes it has among the five standard types.

In addition to the standard antitakeover statutes, unusual and more restrictive statutes were adopted by three states. Pennsylvania and Ohio adopted statutes that enable the "disgorgement" or "recapture" of all the short-term profits made by a hostile bidder. ${ }^{105}$ Massachusetts adopted a statute that mandates a classified board structure even for companies that did not elect to have a classified board in their charter, ${ }^{106}$ a requirement that has a powerful antitakeover effect. ${ }^{107}$

\section{Do Antitakeover Statutes Help States Retain In-State Companies?}

One fact that is immediately apparent from looking at the distribution of incorporations from Table 3 is the presence of "home preference." States generally are better able to attract incorporations from companies headquartered in them than from companies headquartered elsewhere. Even states that hardly attract any out-of-state incorporations are commonly able to retain a significant fraction of their in-state companies. However, states do vary greatly in the fraction of in-state companies that they retain.

Table 3 indicates that states without antitakeover statutes do rather poorly in terms of retaining their companies. Whereas the average fraction of in-state companies retained is $38 \%$, most states with no antitakeover statutes retain a much lower fraction. For example, California retains only $21.77 \%$ of its im-state compamies. Conversely, Table 3 also indicates that states with all the standard antitakeover statutes generally retain a largerthan-average fraction of their $\mathrm{m}$-state companies. For example, Indiana and Wisconsin, each of which offers a "royal fiush" set of five standard antitakeover statutes, retain $69.64 \%$ and $72.22 \%$, respectively, of their in-state companies. Finally, observe that Pennsylvania and Ohio, both of which have the notorious recapture statute, retain a larger-than-average fraction of their in-state companies. Pennsylvania retains $39.52 \%$ of all its in-state companies, and Ohio retains $54.69 \%$ of all its in-state companies. The third "misbehaving" state, Massachusetts, retains $30.00 \%$ of its in-state companies, a figure a bit below the average.

105. See supra notes 13-14.

106. See supra note 12.

107. See Bebchuk et al., supra note 87. 
Of course, these initial observations are merely suggestive, and a more systematic testing is necessary before definite conclusions can be reached. One needs to control for factors other than state antitakeover statutes that might be influencing the incorporation decisions of in-state companies. The Incorporation Study accomplished this by controlling for a number of factors that could conceivably be important, including characteristics of the incorporating company as well as characteristics of the state in which the company is headquartered. ${ }^{108}$

This testing indicates that having a larger antitakeover index-that is, a larger number of antitakeover statutes-makes a state more likely (at a $99 \%$ confidence level, the highest degree of confidence conventionally used in such testing) to retain its in-state companies. Of the different antitakeover statutes, the ones most useful in retaining in-state companies are control-share-acquisition statutes, no-freezeout statutes with a moratorium period of more than three years, and poison-pill-endorsement statutes. ${ }^{109}$

This testing indicates that the effect of adopting antitakeover statutes is not only statistically significant but also large in magnitude. Controlling for other firm and state characteristics, the Incorporation Study estimates that, had states that currently have all the standard antitakeover statutes not adopted them, the fraction of local firms that they retain would have been reduced from the current $49 \%$ of such firms to $23 \%{ }^{110}$ Conversely, it is estimated that adopting all the standard antitakeover statutes by states that currently have no such statutes would have raised the percentage of local firms that they retain from $23 \%$ to $50 \% .^{111}$

Finally, consistent with the observations made above, the testing indicates that providing a recapture antitakeover statute, as do Pennsylvania ${ }^{112}$ and Ohio, ${ }^{113}$ does not adversely affect a state's ability to retain its in-state companies. With respect to the classified board statute of Massachusetts, ${ }^{114}$ the results are mixed, depending on the type of testing done, but overall do not support the prediction that enacting such a statute would hurt an adopting state in the incorporation market. ${ }^{115}$

108. Controlled-for characteristics of the company included the company's sales, Tobin's Q, return on assets, number of employees, and age (when the company went public). Controlled-for characteristics of the state in which the company is headquartered included the state's population, number of located companies, per capita income, ideological leaning, geographic region, and whether the state had adopted the RMBCA (or its predecessor, the Model Business Corporation Act).

109. Guhan Subramanian also tests how the presence of standard antitakeover statutes affects states' ability to retain their headquartered companies, and his results are consistent with those obtained by the Incorporation Study. See Subramanian, supra note 15, at 1839-41.

110. Bebchuk \& Cohen, supra note 15.

111. Id.

112. See supra note 14.

113. See supra note 13.

114. See supra note 12.

115. In contrast to the results of the Incorporation Study, Subramanian concludes that the recapture and classified boards statutes have hurt the ability of the states adopting them to retain 


\section{E. Do Antitakeover Statutes Help States Attract Out-of-State Companies?}

Even if antitakeover statutes help states retain in-state companies, how do these statutes affect their competitive position in attracting corporations with their headquarters in another state? We will now turn to this second dimension of how states fare in the competition over incorporations.

Table 5 displays the distribution of out-of-state incorporations in states other than Delaware, and it lists all the states attracting more than six out-of-state incorporations. Of the ten (excluding Delaware) that are the most successful in attracting out-of-state incorporations, eight have either four or five antitakeover statutes.

\section{TABLE 5}

The Division of THE MARKET FOR OUT-OF-STATE INCORPORATIONS

\begin{tabular}{|l|c|c|}
\hline State & $\begin{array}{c}\text { Number of firms } \\
\text { incorporated in state }\end{array}$ & Percentage \\
\hline DE & 3,744 & $85.23 \%$ \\
\hline NV & 172 & $3.92 \%$ \\
\hline NY & 85 & $1.93 \%$ \\
\hline CO & 58 & $1.32 \%$ \\
\hline NJ & 31 & $0.71 \%$ \\
\hline MD & 29 & $0.66 \%$ \\
\hline FL & 28 & $0.64 \%$ \\
\hline PA & 26 & $0.59 \%$ \\
\hline MN & 20 & $0.46 \%$ \\
\hline UT & 20 & $0.46 \%$ \\
\hline VA & 18 & $0.41 \%$ \\
\hline GA & 12 & $0.27 \%$ \\
\hline WY & 12 & $0.27 \%$ \\
\hline IN & 11 & $0.25 \%$ \\
\hline WA & 11 & $0.25 \%$ \\
\hline CA & 10 & $0.23 \%$ \\
\hline MA & 10 & $0.23 \%$ \\
\hline MO & 10 & $0.23 \%$ \\
\hline
\end{tabular}

companies. See Subramanian, supra note 15 , at $1843-44$. He uses one dummy variable to stand for the presence of either a recapture or a classified board statute and he controls only for company characteristics but not for state characteristics other than their antitakeover statutes. Id. Running the same regressions as Subramanian did, the Incorporation Study obtained similar results to his. See Bebchuck \& Cohen, supra note 15. However, in order to allow for the possibility that the incorporations market did not treat recapture and classified boards statutes in the same way, the Incorporation Study used a separate dummy variable for each of these statutes. With this specification, the recapture statute was no longer found to hurt the states adopting it even without introducing state characteristics. Once state characteristics were controlled for, the results no longer indicate a negative effect due to the classified board statute. 
TABLE 5 (cont.)

\begin{tabular}{|l|c|c|}
\hline State & $\begin{array}{c}\text { Number of firms } \\
\text { incorporated in state }\end{array}$ & Percentage \\
\hline $\mathrm{KS}$ & 8 & $0.18 \%$ \\
\hline $\mathrm{NC}$ & 8 & $0.18 \%$ \\
\hline $\mathrm{TX}$ & 8 & $0.18 \%$ \\
\hline $\mathrm{OH}$ & 7 & $0.16 \%$ \\
\hline $\mathrm{TN}$ & 6 & $0.14 \%$ \\
\hline Other & 49 & $1.12 \%$ \\
\hline Total & 4,393 & $100 \%$ \\
\hline
\end{tabular}

The figures in Table 5 provide no basis for concluding that the three "outlier" states, which have been blacklisted as extreme, have been hurt in the market for out-of-state incorporations. Pennsylvania holds a respectable seventh place (excluding Delaware) in terms of the number of out-of-state companies it attracts. Massachusetts and Ohio are both comfortably in the top half of the states in their ability to attract out-of-state companies.

Again, definite conclusions cannot be drawn without controlling for characteristics of states and firms. The Incorporation Study conducted such testing, and its conclusions confirm what is suggested by the above observations. The findings indicate that having a higher antitakeover index makes a state more attractive-again, at a high $99 \%$ confidence level-for out-of-state incorporations. Of the different types of standard antitakeover statutes, the ones most helpful for attracting out-of-state incorporations are control-share-acquisition statutes and poison-pill-endorsement statutes.

The testing also provides clear results with respect to the two types of extreme antitakeover statutes. Neither a classified board statute nor a recapture statute has a statistically significant effect on the ability of a state to attract out-of-state incorporations. Thus, again, there is no empirical basis for concluding that the incorporations market penalizes states adopting extreme antitakeover statutes.

\section{F. Reconsidering Established Positions}

States have been busy over the last three decades adopting antitakeover statutes. They have often gone back to the drawing board more than once, either because earlier statutes were held unconstitutional or because they wanted to take advantage of newly hatched types of antitakeover statutes. Many states have ended up with most or all of the standard antitakeover statutes. However, the enthusiasm of state officials for such statutes has not been matched by shareholders. The passage of antitakeover statutes has generally been accompanied by a negative reaction or, at best, no reaction in the stock price of the companies governed by them. 
As the pro-state competition position has long been the dominant view in corporate law scholarship, most students of corporate law would agree with the following two propositions:

(1) Amassing state antitakeover statutes does not serve shareholders; and

(2) State competition rewards, and thereby induces, adopting rules that serve shareholders.

Facing a possible tension between these two propositions, supporters of state competition have sought to reconcile them by advancing an additional proposition:

(3) State coinpetition does not reward, and indeed might discourage, the amassing of antitakeover statutes.

However, as suggested by the observations made above, and by the reported results of the Incorporation Study, proposition (3) is inconsistent with the evidence. This implies that the comnonly held view, which consists of propositions (1) and (2), can no longer be maintained. Those who have held this view should revise their position on at least one of these two propositions. Although the evidence discussed in this Part enables rejecting (3), it does not speak directly to which revisions should be made. What is certain, however, is that the conventional picture of state competition needs to be revised.

Our own view is that, although some antitakeover statutes might not be harmful and at times arguably beneficial, ${ }^{116}$ not all are; ${ }^{117}$ and state competition thus provides excessive incentives to restrict takeovers. If the "race to the top" story were true, it would be particularly puzzling that competition has failed to discipline the states adopting the most extreme antitakeover statutes. Although they have been the subject of strongly negative market reaction and widespread criticism by scholars of corporate law, these statutes have been on the books for a long time now. Still, the states having these statutes continue to fare respectably in the incorporation market-both in terms of retaining im-state companies and in terms of attracting out-of-state companies.

Although puzzling for the conventional race-to-the-top view, the adoption of antitakeover statutes and the evidence presented in this Part are not puzzling at all to those who hold a skeptical account of state

116. Control-share-acquisitions statutes, for example, might be helpful in the absence of other arrangements in addressing pressure to tender problems. See Lucian A. Bebchuk, Toward Undistorted Choice and Equal Treatment in Corporate Takeovers, 95 HARv. L. Rev. 1695 (1985); LuClan A. Bebchuk \& Oliver Hart, Takeover Bids vs. Proxy Fights in Contests for Corporate ConTrol (Nat'1 Bureau of Econ. Res., Working Paper No. 8633, 2001).

117. Poison-pill-endorsement statutes, for example, can produce excessive protection from takeovers for the large fraction of companies that have classified boards. See Bebchuk et al., supra note 37. 
competition. On this account, state competition can be expected to produce excessive protections from takeovers. It is a natural consequence of the competitive process itself as currently structured. This process provides states with incentives to place weight on managers' interests, rather than solely on shareholders' interests, when selecting rules that have a major effect on managers.

\section{CONCLUSION}

A recurring claim in the literature on state competition over corporate charters is that the existing empirical evidence decisively supports the view that state competition benefits shareholders. Those who are more skeptical of state competition (as currently structured) and the regulatory choices it has produced, have often been portrayed as fighting against established empirical facts. This Article has shown that the body of empirical evidence on which supporters of state competition rely does not warrant their claims of empirical support.

First, the evidence does not establish that Delaware incorporation produces an increase in share value. Although studies have found an association between Delaware incorporation and higher shareholder value, there are significant questions with respect to the generality, robustness, and magnitude of this correlation. More importantly, correlation does not imply causation; any correlation of the sort alleged could reflect the underlying differences between firms that elect to incorporate in Delaware and those that do not.

Second, even if it were established that Delaware incorporation is marginally beneficial to investors in the existing state-competition equilibrium, this marginal benefit does not imply that state competition benefits investors overall. In a race-toward-the-bottom equilibrium in which all states are induced by competition to choose suboptimal rules (on certain issues), incorporation in the dominant state might still be beneficial as a result of network effects and the dominant state's institutional infrastructure.

Third, we have shown that, contrary to clains made by supporters of state competition, the empirical evidence does not establish that state competition rewards moderate takeover regimes rather than the amassing of antitakeover statutes. In particular, the claims that Delaware is more hospitable to takeovers than average, and that states hostile to takeovers are penalized in the incorporation market, do not have a solid empirical basis.

Finally, we have discussed a new approach to the empirical study of state competition based on analyzing the determinants of companies' decisions regarding where to incorporate. An empirical study conducted by us using this approach indicates that, contrary to the beliefs of state competition supporters, this competition provides incentives for states to offer 
antitakeover protections. States that amass antitakeover statutes fare better both in retaining in-state companies and in attracting out-of-state companies. Indeed, there is scant evidence that states with extreme antitakeover statutes, widely viewed as detrimental to shareholders, have been penalized in the incorporation market.

Our demonstration that the view supportive of state competition in corporate law (as currently structured) does not have the empirical basis believed to exist by supporters has significant policy implications. It calls for a reconsideration of established positions on the merits of state coinpetition and the role of federal law in this area. It also calls for a reassessment of the body of corporate law that has been produced by state competition. In the key areas that directly affect managers' private interests, the rules that have been produced by state competition should not be regarded as presumptively value-enhancing.

In particular, our analysis questions whether the extensive takeover protections currently afforded managers in the United States actually serve shareholders' interests. Contrary to prevailing beliefs, we have shown that state competition does not reward moderation in takeover protection. The proliferation of antitakeover statutes and protections might have been, at least partly, the product of incentives created by the incorporation market. These findings lend support to proposals for federal intervention in the takeover area, either in the form of mandatory federal takeover rules, which one of us supported in an earlier work, ${ }^{118}$ or in the form of "choiceenhancing" intervention, which we introduced in subsequent joint works. ${ }^{119}$

In sum, more attention needs to be paid to the possibility that state competition might produce adverse incentives in some important areas of corporate law. For this to happen, scholars of corporate law must first recognize that the empirical evidence does not rule out this possibility. We hope that this Article will help bring about such a recognition.

118. See Bebchuk, supra note 2.

119. See Bebchuk \& Ferrell, A New Approach, supra note 3; Bebchuk \& Ferrell, Federal Intervention, supra note 3. 
